NBER WORKING PAPER SERIES

\title{
THE IMPACT OF PERMANENT RESIDENCY DELAYS FOR STEM PHDS: WHO LEAVES AND WHY
}

\author{
Shulamit Kahn \\ Megan MacGarvie \\ Working Paper 25175 \\ http://www.nber.org/papers/w25175 \\ NATIONAL BUREAU OF ECONOMIC RESEARCH \\ 1050 Massachusetts Avenue \\ Cambridge, MA 02138 \\ October 2018
}

We thank Chelsea Carter and Zijie Zhu for excellent research assistance. We thank Gabriele Cristelli, Sari Kerr, Bill Kerr, Jim Rebitzer, David Spitzer and Bruce Weinberg for helpful suggestions. We also thank those at NSF NCSES and at NORC for enabling this research. However, all analysis and conclusions are solely the work of the authors and not NSF or NORC. This work was supported by NSF grant SES-1538716. The views expressed herein are those of the authors and do not necessarily reflect the views of the National Bureau of Economic Research.

NBER working papers are circulated for discussion and comment purposes. They have not been peer-reviewed or been subject to the review by the NBER Board of Directors that accompanies official NBER publications.

(C) 2018 by Shulamit Kahn and Megan MacGarvie. All rights reserved. Short sections of text, not to exceed two paragraphs, may be quoted without explicit permission provided that full credit, including $\odot$ notice, is given to the source. 
The Impact of Permanent Residency Delays for STEM PhDs: Who leaves and Why Shulamit Kahn and Megan MacGarvie

NBER Working Paper No. 25175

October 2018

JEL No. J61,O15,O3

\begin{abstract}
$\underline{\text { ABSTRACT }}$
This paper assesses whether delays in obtaining permanent residency status can explain recent declines in the share of Chinese and Indian PhD graduates from US STEM programs who remain in the US after their studies. We find that newly-binding limits on permanent visas for those from China and India with advanced degrees are significantly associated with declines in stay rates. The stay rate of Chinese graduates declines by 2.4 percentage points for each year of delay, while Indian graduates facing delays of at least $51 / 2$ years have a stay rate that is 8.9 percentage points lower. The per-country permanent visa cap affects a large share of STEM PhDs who are disproportionately found in fields of study that have been crucial in stimulating US economic growth yet enroll relatively few natives. Finally, results suggest that the growth of science in countries of origin has an important influence on stay rates, while macroeconomic factors such as GDP per capita affect stay rates only via their impact on science funding. We conclude that percountry limits play a significant role in constraining the supply of highly skilled STEM workers in the US economy.
\end{abstract}

\author{
Shulamit Kahn \\ Boston University \\ School of Management \\ 595 Commonwealth Ave. \\ Boston, MA 02215 \\ skahn@bu.edu \\ Megan MacGarvie \\ Boston University \\ School of Management \\ 595 Commonwealth Avenue, Room 522H \\ Boston, MA 02215 \\ and NBER \\ mmacgarv@bu.edu
}


The US trains a large share of the world's PhD scientists, and in some fields of science and engineering, students of foreign origin represent the majority of doctoral degrees granted by US programs. Students produced by these programs have made important contributions to innovation at US universities and firms (Stuen et al. 2012, Hunt and Gauthier-Loiselle 2010). Currently, the countries that send the most STEM doctoral students to the US - China and India - are also among those with the highest fraction of students who stay in the US after their studies (Finn 2014, NSF 2016). However, the fraction of Chinese and Indian doctoral recipients reporting definite plans to stay in the US has fallen in the last decade (NSF Science and Engineering Indicators 2018 Appendix Table 3-21).

In this paper, we investigate possible reasons for the decline in stay rates (the probability of remaining in the US) of Chinese and Indian STEM PhDs, with a particular focus on the impact of limitations on the number of employment-based permanent residency visas available to these workers. We analyze the EB-2 visa category, which applies to those holding advanced degrees and allows temporary residents with these degrees to become permanent residents. We exploit changes over time in the rate at which EB-2 permanent residency visas (also known as "green cards") are granted to applicants as a result of binding constraints on the number of visas available per country. These changes have created long wait times for Chinese and Indian applicants only, while applicants from other countries have not faced binding visa limitations. Our analyses allow us to measure how tighter visa policies for those with advanced degrees affect the stay rates of foreigners who obtain US STEM PhDs. ${ }^{1}$

Our main data come from the NSF's Survey of Doctorate Recipients (SDR). Starting in 2010, this database includes scientists with US PhDs who have left the US. This allows us to provide some of the first evidence on the determinants of longer-term stay rates. The scientists we study were temporary

\footnotetext{
${ }^{1}$ Applicants employed by universities and other nonprofit institutions such as hospitals and government agencies are not subject to any cap on employment-based visas (SEC. 103 of American Competitiveness in the Twenty-first Century Act of 2000). However, we do not limit our analysis to those working in the private sector, since the choice of sector is part of the location choice process. In robustness checks, we analyze whether the visa delays are correlated with larger propensities to work in nonprofits.
} 
residents when they obtained their PhDs between 2001 and 2013 and are observed in the 2010, 2013 and 2015 SDR waves, which allows us to provide evidence on the stay rates of these foreign-born scientists over a longer time frame post-PhD than has previously been reported. The SDR is linked to the NSF's Survey of Earned Doctorates (SED), the source for intended post-PhD locations used by Grogger and Hanson (2015) and others to proxy stay rates of people receiving US PhDs. We find that intention to stay in the US measured upon graduation by NSF's SED is an important predictor of longer term stay rates, but that the longer term propensity to stay in the US exhibits some very different patterns.

Country-based limits on EB-2 green cards are associated with reductions in the stay rates of Chinese students of 2.4 percentage points (ppt.) per year of delay relative to students from the rest of the world, while Indian students are only affected by very long delays in visa processing. Indian students facing delays of $5 \frac{1}{2}$ years or more have a relative stay rate that is about $8.9 \mathrm{ppt}$. lower. This relative reduction in the stay rates of Chinese and Indian students is estimated after controlling for macroeconomic and scientific conditions in home countries, and is robust to controlling for countryspecific time trends. These results suggest that the decline in the relative stay rate is not explained by improvements in living and working conditions in China and India, but rather the effects of immigration policy on the attractiveness of working in the US.

In addition to measuring the effects of visa availability, we estimate the relationship between stay rates and home countries' macroeconomics and scientific research base. Although prior research on stay rates has typically not explicitly controlled for the strength of the science enterprise in the home country, we find that this factor is an important predictor of return rates, with students from the lowest-ranked countries in terms of publication output exhibiting stay rates that are $13 \%$ higher than those from the highest-ranked countries. The quality of articles produced in the home country (as measured by citations per article) is also a strong predictor of return to the home country.

This paper also examines which fields of study are most affected by this combination of factors, 
and shows that counter-productively, the fields with the greatest apparent excess demand for STEM PhDs are also the fields with the greatest numbers of graduates affected by visa restrictions. Thus, the rapid improvement in the level of scientific activity in home countries and limits on the number of immigrants by country of origin combine to discourage international students from remaining in the country after graduation, reducing the supply of workers available to be hired by innovative firms in the US.

\section{Prior Literature}

The current paper builds upon Grogger and Hanson (2015), which uses data from the NSF's SED, a census administered to all doctoral recipients in the US at the time of $\mathrm{PhD}$ completion, to measure stay rates. The SED has the advantage of being very large and covering a long time span, but has the disadvantage of only listing respondents' plans to stay in the US at the time of PhD completion, not whether they actually remained. Nonetheless, Grogger and Hanson establish that SED intentions to stay are positively associated with the growth of GDP per capita in the US at the time of $\mathrm{PhD}$, negatively associated with prosperity in the home country, and negatively associated with the level of democracy in the home country. Finn (2014) matches the SED to 2011 Social Security data to obtain the only nationally representative estimates to date of stay rates over early careers prior to the international SDR that we use. Most recently, NSF's Science \& Engineering Indicators 2018 has also used the SDR to measure stay rates.

Khosla (2018) has also addressed the impact of per-country permanent residency limits on the stay rates of STEM doctorates, although using only the 2010 and 2013 surveys of the SDR and the SED. We replicate some of Khosla's results but obtain results that contradict one major finding, specifically that there was no effect of visa restrictions on stay rates by six years after $\mathrm{PhD}$. Instead, we find that there are sustained effects. In addition, we provide a more comprehensive analysis of the impacts of EB-2 delays, including differences between the effect on Chinese and Indians, the importance of the home 
country's scientific environment, the fields that lose US scientists due to the policy, and how the visa delays affect the kinds of jobs the scientists take.

Earlier work on permanent residency includes Hunt's (2017) study of job-changing among temporary residents. She finds that when temporary residents become permanent residents, there is a $20 \%$ increase in the rate of job changing. This suggests that job mobility of temporary residents is constrained. However, using data from 6 large Indian IT firms operating in the US, Depew, Norlander and Sorensen (2017) find a significant amount of inter-firm mobility among those with H-1B and L-1 temporary visas that varies over the earnings distribution and over the business cycle.

Another related paper is Brentschneider and Dai (2017), which analyzes the SDR and obtains several findings consistent with those of this paper, including the importance of science infrastructure in the home country and financial support for graduate study from foreign sources for predicting stay rates of the. Breschi et al. (2018) compile a large dataset of Indian inventors from patent data matched to LinkedIn profiles, and document an increase in recent decades in the propensity to return to India across cohorts of Indians who came to the US to study. Soon (2008) analyzes survey data on international students in New Zealand, and finds that $82.6 \%$ of those who initially intended to return to their home country before beginning their studies in New Zealand ultimately did return, while $37.1 \%$ of those who originally intended not to return did return.

Some of the prior literature has focused on the extent to which foreign students might be selected on ability, and how the return migration decision is affected by ability. Bratsberg (1995), Borjas and Bratsberg (1996), and Grogger and Hanson (2015) focus on whether return migration accentuates the selection effect of migration. Borjas and Bratsberg (1996) model the decision to migrate, whether temporarily or permanently, as a function of expected earnings in the source and receiving countries, the potential migrant's skill/ability and returns to skill at home and abroad, and a random parameter. They find that, as long as the returns to skill are higher in the receiving country, migrants come from the upper 
part of the ability distribution and those who stay permanently in the receiving country will be those with the highest ability. Breschi et al (2018) find evidence of positive selection of foreign students with US degrees remaining in the US based on the fact that Indians who have obtained Master's or PhD degrees in the US are less likely to return than those who have merely obtained Bachelor's degrees in the US. However, Brentschneider and Dai (2017) find no relationship in the SDR between return rates and the research quality of the US university from which foreign students obtain their PhDs. ${ }^{2}$ Kato and Sparber (2013) find that H-1B visa restrictions have decreased applicants to the US from the top ability levels (as measured by SATs). They offer two possible reasons for this. First, high-ability students may be disproportionately discouraged from applying to US colleges if they are more aware of the effects of tightened immigration policy on job opportunities. Second, those foreign students with high levels of ability may be most affected by tightened immigration policy because low-ability students are unlikely to be offered jobs in the US irrespective of the policy environment.

Preferences have been studied as well. In a study focused specifically on the return intentions of Chinese students abroad, Zeithammer and Kellogg (2013) perform a conjoint analysis of student preferences to assess the tradeoffs associated with staying in the US vs. returning to China. The authors find that approximately $70 \%$ of Chinese STEM PhDs would prefer to return to China if offered the same salary as they expect to receive in the US, but that salary differentials between the US and China keep the majority of them in the US. By contrast, in a survey of recent PhDs in Chemistry, Ganguli and Gaule (2018) find that international students have stronger preferences for remaining in the US for post-doctoral training than do domestic students, after controlling for test scores and career preferences. Roach, Sauermann and Skrentny (2018) survey STEM PhD students before and after graduation, finding that entrepreneurial preferences are often not acted on post-PhD. This may be due to the US visa systems

\footnotetext{
${ }^{2}$ Brentschneider and Dai measure research quality using data from the National Research Council's 2006 ranking of doctoral programs and a ranking of the top 200 programs in terms of research expenditure from the Center for Measuring University Performance.
} 
requiring employment-based immigrants to have stable employment.

\section{Data}

Our main data come from the 2010, 2013 and 2015 waves of the National Science Foundation's International Survey of Doctoral Recipients (ISDR) and the Survey of Doctoral Recipients (SDR). These are partially longitudinal surveys of a sample of individuals receiving doctorates in the US. The NSF has matched these people to the NSF's Survey of Earned Doctorates (SED), which contains a snapshot of information on approximately $90 \%$ of doctoral recipients at the time of doctoral receipt. The NSF began systematically following doctoral recipients even if they moved abroad only from 2001 and on, although the first SDR to incorporate these PhDs was in 2010. We therefore include in our analysis only those who earned their doctorates in 2001 or later and use only the SDR waves starting in 2010.

In 2015, the SDR drew a whole new sample more than twice the size of the 2013 SDR, sampling from past SEDs (and keeping only a small fraction of those who had been in the $2013 \mathrm{SDR}^{3}$ ). This added a large number of observations of people living abroad (5,431 of those employed compared to 3,439 in 2013). This also gives a much larger variety of country-of-origin/field combinations. The 2015 SDR response rate was $66 \%$, down from a $70 \%$ response rate in 2013 . The NSF has worked hard to estimate weights that they believe make the sample representative. However, given the differences in methods of creating the 2015 sample, we warn readers that identifying trends between 2013 and 2015 may not be as accurate as when using previous SDRs. Also, because the probability of finding a new sample of US PhDs who left the US long ago was likely the most fraught with response bias, we continue to ignore those who received $\mathrm{PhDs}$ prior to 2001.

We restrict attention to people with doctorates in STEM fields who are currently employed and

\footnotetext{
${ }^{3}$ In total, of the 16,215 temporary residents at $\mathrm{PhD}$ with adequate data that we use in our analysis, 11,347 were observed only once. Of the others, 1,385 were in all three surveys - 2010, 2013 and 2015. 3,483 respondents were in two surveys only (2,836 were in 2010 and 2013 only; 485 in 2013 and 2015 only; and 162 in 2010 and 2015 only).
} 
who were temporary residents at $\mathrm{PhD} .{ }^{4}$ The sample contains 22,470 observations of temporary residents at time of $\mathrm{PhD}$ completion who were working during the survey year, ${ }^{5}$ of whom $68.2 \%{ }^{6}$ are in the US in the survey year, with $13.7 \%$ of these reporting that they had become naturalized citizens, $52.5 \%$ reporting permanent resident status, and $32.2 \%$ remaining temporary residents.

We discuss the sources of data on visa delays and country-level variables in the Variables section.

\section{The Empirical Model}

Our analysis first estimates how EB-2 visa delays affect the probability that a temporary resident remains in the US after $\mathrm{PhD}$ completion, conditional on a wide variety of factors including fixed effects for $\mathrm{PhD}$ year. It then examines the relationship using additional variables for visa delays and conducts robustness checks.

The control variables are factors that shift both foreign US PhD recipients' preferred choices for location and job characteristics (supply) and factors that affect the availability and characteristics of job offers (demand) in the US, home country and third countries. These are in addition to the visa restrictions that determine whether the scientists can be offered a job and what type of job they can be offered. Thus, our empirical model should be thought of as a reduced form.

The timing and other aspects of our data make it difficult to know for all respondents exactly when the location decision was made. As a result, we cannot be certain of the visa policy, macroeconomic and other conditions at the decision point. Thus, for most people we know their actual location at one point of time - i.e. in 2010, 2013 or 2015 - which could be between 1 and 13 years post-PhD. ${ }^{7}$ However

\footnotetext{
${ }^{4}$ If citizenship status was missing at graduation and in a subsequent SDR survey year the individual was coded as a temporary resident, we classify these as a temporary resident at time of $\mathrm{PhD}$ (this is true of 402 observations). We exclude a handful of people who a birth state inside the US but say they were temporary residents. People born in Puerto Rico or a US territory are classified as non-foreign.

${ }^{5}$ Only those working who would be affected by employment-based visas. Those not employed are $4.41 \%$ of the total SDRs' population, $3.52 \%$ of those who are temporary residents at $\mathrm{PhD}$.

${ }^{6}$ The percentages given here and throughout the paper are all weighted.

${ }^{7}$ See footnote 3 .
} 
we do not know when the respondent actually moved to his or her current location. Moreover, even if we know when they actually moved, we cannot know when they made the decision to move. However, it is crucial for us to assign a time to the location decision, because we need to connect it with the visa policy and country conditions around that point of time. That is, we don't know if the choice was actually made around the time of $\mathrm{PhD}$ receipt, or after additional training/working several years in the US (e.g. on a postdoc or in Occupational Practical Training or OPT), or even whether it was remade every year. We only know that a choice was made (even if it is a temporary one) by the time they appear in the survey.

Consequently, we make a reasonable assumption, estimate our model, and then test it against other possible timing assumptions. Specifically, we assume that they make their location choice given the information around the time of their $\mathrm{PhD}$, which seems reasonable since at that point, they are forced to make $a$ choice then. Moreover, we do not assume that they base that decision on the current visa delay during the month of graduation. After all, visa delays both trend and vary idiosyncratically (as shown in Figure 1). Instead, we use the moving average of the visa delay from 6 months before to 6 months after the respondent's graduation month as the typical delay they can expect to face if they remain in the US. ${ }^{8}$

We also test how sensitive our results are to alternative assumptions about the timing of the decision and assess which assumption seems to most accurately predict the stay rates. For instance, we model what happens if the $\mathrm{PhDs}$ base their decisions on the visa policy 3 years post- $\mathrm{PhD}$, and compare this to the assumption that decisions are based on conditions in the survey year. We find that the variables measured at $\mathrm{PhD}$ are most accurate predictors of location. ${ }^{9}$

The implicit assumption in our model is that people tend to not change their country year-to-year once they leave the US. We base this assumption partially on the evidence we have from the approximately 5,000 graduates of foreign origin who were observed in more than one survey. ${ }^{10} 94.6 \%$ of

\footnotetext{
${ }^{8}$ In contrast, Khosla's (2018) EB-2 variable was the delay length in a single month one year post-PhD.

${ }^{9}$ Regressions available from authors upon request.

${ }^{10}$ See footnote 3 .
} 
those observed in the home country were still there the next survey. An even higher percentage, $96.7 \%$, of those who were observed out of the country in one survey were also out of the US in the next. This corroborates findings from our previous work- albeit it on a much smaller sample - where more than $90 \%$ of US STEM PhDs who returned to their home countries did not move back to the US in their early careers (Kahn and MacGarvie 2016a).

Note that we do know from the SED responses whether the graduate intends to remain in the US for the period immediately following the $\mathrm{PhD}$. However, we do not use this information as evidence of actual location, because many new graduates may respond about the intended location of their post-PhD additional training - as postdocs or OPT - even if they intend to leave the US after that. Also, those who intend to stay permanently may be unable to find a suitable job or to get a temporary work visa. Later in this paper, we empirically analyze the relationship between intended location, actual location and visa delay length.

Except for a short period in the first academic year included in our survey (2001), EB-2 visa delays occurred starting in the middle of 2005. Delay lengths generally trended upward over time after that. ${ }^{11}$ We must therefore be careful to add variables that control for secular trends in stay rates. Rather than including a single time trend, we capture time with dummies for each $\mathrm{PhD}$ year to impose the least possible structure on the relationship between stay rates and time. We also include dummies for the survey year. We note that with year of PhD and survey year dummies, adding dummies for years-since$\mathrm{PhD}$ would be perfectly collinear. ${ }^{12}$ In robustness checks, we instead use dummies for years-since-PhD.

China and India have both experienced significant economic growth since the beginning of our sample period, and improvements in living conditions may have encouraged some graduates of US programs to return home. Consequently, stay rate time trends for India and China may be different from

\footnotetext{
${ }^{11}$ We discuss the early 2001 visa delays in more detail in the following section.

12 They actually would not be completely collinear, but only because we happened to use the exact dates (month and year) to calculated the time between $\mathrm{PhD}$ and the survey.
} 
stay rate time trends for the rest of the world. We will address this in several ways.

First, we include China and India fixed effects to pick up time-invariant features of the attractiveness of the home country. We also include a rich set of time-varying controls for economic, scientific and political conditions in the home country, including GDP per capita of the home country (relative to the US), the R\&D/GDP ratio, the country ranking in scientific articles, the number of citations received by these articles, and the country's level of democracy.

In addition to these controls, we estimate additional specifications in which we include countryspecific time trends (that is, the China dummy interacted with the year of $\mathrm{PhD}$, and a similar interaction term for India). These interactions control for differential changes in the attractiveness of China and India over time during our sample. ${ }^{13}$ The fact that we continue to estimate significant effects after including these interaction terms implies that any improvement in the attractiveness of China and India would have to coincide precisely with the timing of the introduction of the visa delays in the US.

To control for changing Chinese policies aimed at increasing return rates of Chinese scientists working in the west, we also perform analysis excluding observations most likely to be affected by policies in China.

Finally, we also perform placebo tests that show that the visa effects found are not relevant for Chinese or Indian permanent residents or naturalized citizens, or for temporary residents from neighboring and culturally similar countries (Pakistan and Taiwan) who are not constrained by visa limitations. The absence of an effect for these groups provides reassurance that our results are indeed related to US visa policy for temporary residents, rather than something affecting all Chinese/Indian immigrants or temporary residents from similar countries.

\footnotetext{
${ }^{13}$ This makes the model essentially a standard differences-in-differences model. We do not use this as our base model because of our concern about the interpretation of $\mathrm{PhD}$ year. Thus, we cannot disentangle time trends by cohort (PhD year), time trends as individuals age, and calendar year differences so it is difficult understanding what these "time trends" are measuring.
} 
All of these results are described in detail below.

\section{Variables}

Appendix Tables 1a and 1b show summary statistics for the variables used in this analysis.

These variables are explained below.

\section{Employment-Based Permanent Residency Visa Variables}

According to the Immigration Act of 1990, immigrants to the US can become permanent residents via a family-based visa or an employment-based visa, and the act sets out the number and types of employment-based visas made available each year. There are $140,000^{14}$ (or more) employment-based permanent visas available each year, excluding those awarded to non-profit employers, particularly universities and hospitals. ${ }^{15}$ Of these, 40,040 are allocated to persons of extraordinary ability or multinational managers and executives (EB-1). Another 40,040 are allocated to members of the professions holding advanced degrees (or with exceptional abilities) - the EB-2 category. It is in this category that employers typically request permanent visas for STEM PhDs. The EB-2 category also gets any leftovers if the EB-1 applicants do not use up their quota of 40,000.

Within the EB-2 category, there is a per-country limitation of $7 \%$ of the maximum number of family-based plus employment-based permanent visas, which means approximately 25,620. If the number of applications from a country exceeds that, processing of the application is put in a queue. The USCIS works through each country's queue in order of application date. Each month, it publishes its "priority dates" - the dates of application that the government is currently processing for each type of permanent

\footnotetext{
14 This is a minimum. In some years, the actual number is slightly more. For instance, in FY2012 ending in Sept 2012, there were 144,951. https://en.wikipedia.org/wiki/Visa_Bulletin_Employment-based_Preferences_Cutoff Dates.

15 The relevant law is the Immigration Act of 1990. Universities and non-profits are not subject to this cap.
} 
visa from each country that reached its $7 \%$ limit - in the Department of State's visa bulletins. ${ }^{16}$ We use these to calculate the delay - the difference between the date of $\mathrm{PhD}$ receipt and the priority date at that month (and from these calculate the moving averages.)

The 7\% maximum first delayed India's EB-2 applications in November 1991 and China's in October 1993, and during the 1990s each of these countries faced delays some months but not others. The American Competitiveness in the Twenty-First Century Act of 2000 enabled the per-country $7 \%$ ceiling for all EB visa applications "to be surpassed for individual countries that are oversubscribed as long as visas are available within the worldwide limit for employment-based preferences." (Argueta 2016). This Act was first passed in January of 2000 and signed into law in October, although it took until May of 2001 until the USCIS had no queue remaining even for India and China. Our data starts with the cohort graduating in the academic year 2001, a cohort which either faced no queue at graduation or knew that the queue would soon disappear. It should not, therefore, have affected location plans. We model stay rates under this assumption, although in robustness checks re-estimate our main models as if the earliest graduates (in fall of 2000) faced actual delays.

There continued to be no EB-2 delay through September 2005. However, in the fiscal year ending in September 2005, there was a total of almost 250,000 employment-based visas granted (Argueta 2016), signaling that in the future the demand for employment-based visas would be entirely used up. Therefore, starting in October of 2005 , the $7 \%$ limit applied. The only two countries of origin whose permanent visa EB-2 pending applications exceeded the 7\% limit in October 2005 and practically every month since are India and China.

We show the delay length due to EB-2 visa backlog in Figure 1. The backlog of pending applications are of different lengths each month and are larger for India than China. Thus, the waiting

\footnotetext{
${ }^{16}$ For instance, https://ravel.state.gov/content/travel/en/legal/visa-law0/visa-bulletin/2014/visa-bulletin-forseptember-2014.html. When visa bulletins were not available on the State Department's site directly, we found them on the website immihelp, for instance https://www.immihelp.com/visa-bulletin/september-2002.html
} 
periods for employment-based permanent visas have varied both across countries of origin and over time and this allows us to identify the delays' effects.

Some of the month-to-month variability is due to USCIS mis-estimating the number of applicants it had already processed until late in the fiscal year and therefore temporarily processed people with earlier (or later) application dates than planned. As a result, we use 13 month moving averages rather than single month's delays, also shown in Figure $1 .{ }^{17}$

\section{Foreign Support during Graduate School}

Many students receive financial support for their PhD studies from the government of their country of origin. Examples of this include the BECAS Chile Scholarship and Mexico's CONACYT fellowship program. Many of these students receive J-1 visas for study in the US, which require them to return to their country for two years after they graduate before applying for a US employment-based visa. ${ }^{18}$ Some specific programs in foreign countries also stipulate that students return to the home country after completing their studies, irrespective of their US visa requirement.

Although we do not directly observe whether respondents had a J-1 visa for their studies, our data allow us to measure whether people had received money for at least partial funding from foreign governments, which we have made into a dummy. In our sample of those with temporary visas at $\mathrm{PhD}$, 4.1\% had received foreign support (Appendix Table 1).

\section{Control Variables: Demographics, family and education}

Variables capturing demographics and family at the point of $\mathrm{PhD}$ no doubt affect the decision of where to locate and we include them in our stay-rate regressions. These include dummies for Female,

\footnotetext{
${ }^{17} \mathrm{We}$ also needed to make some reasonable assumption about the end points. We assumed that no graduates expected a visa delay until new delays were announced in October 2005. For the first few months that EB-2 delays were imposed on India and China, we averaged the delay over those months from -6 to +6 months that did have a delay.

${ }^{18}$ Kahn and MacGarvie (2015) document the high return rates of students funded by the Foreign Fulbright Fellowship Program, funded by the US department of state. Students receiving funding from this program also receive $\mathrm{J}-1$ visas.
} 
female and married at $\mathrm{PhD}$, female and children at $\mathrm{PhD}$, male and married at $\mathrm{PhD}$, male and children at $\mathrm{PhD}$, age at $\mathrm{PhD}$, Black, Asian, Hispanic, and whether the father completed college. ${ }^{19}$

A second group of control variables relate to the $\mathrm{PhD}$ education of the respondent. We control for field of study of highest degree using 2-digit SED categories listed in Appendix Table 2 (for example, computer science, mathematics and statistics, etc.). We also control for the prestige or quality of the doctoral institution. This data comes from the Academic Ranking of World Universities (ARWU), 20032016, which is available at the institution level for the top 500 universities and at the broad field level for the top 200 universities. ${ }^{20}$ We break this into 9 categories, $(1-10,11-25,26-50,51-100,101-201,201-300$, 301-400, 401-500, and unranked). The ranking of the $\mathrm{PhD}$ institution is the main proxy we have for the academic ability and/or the quality of education of the respondent. We include a dummy for whether the $\mathrm{PhD}$ was granted by a medical school and another dummy for whether the person is currently in a postdoc. As discussed above, regressions also include fixed effects for PhD year and for survey year.

\section{Control Variables: Country Characteristics}

In addition to these personal control variables, the regressions control for the characteristics of home countries that we derive from other sources. Real GDP per capita (in PPP constant 2011 international \$) and R\&D expenditure as a percent of GDP come from the World Bank's World Development Indicators. From these variables we compute the ratio of real home country GDP per capita to US GDP per capita in the year before $\mathrm{PhD}$ receipt, ${ }^{21}$ home country $\mathrm{R} \& \mathrm{D}$ expenditures as a percent of GDP in the year before $\mathrm{PhD}$ receipt, and a variable for whether data on $\mathrm{R} \& \mathrm{D}$ is missing (which is

\footnotetext{
${ }^{19}$ Family characteristics during the survey year may very well be endogenous and are highly correlated with family characteristics at $\mathrm{PhD}$, so were left out of the regressions.

${ }^{20}$ These fields are: Natural Sciences and Mathematics, Engineering/Technology and Computer Sciences, Life and Agriculture Sciences, and Clinical Medicine and Pharmacy. Available at http://www.shanghairanking.com/, accessed July 2017.

${ }^{21}$ We also experimented using other GDP-based variables as we discuss in the results section. Note that the World Bank data did not include Taiwan, which we added using IMF data.
} 
typically true for countries with so little R\&D that they do not track it. $)^{22}$ Following Grogger and Hanson (2015) we use the average Polity IV scores in the previous three years as a measure of the democratization of the home country (Marshall and Jaggers 2002). ${ }^{23}$ We incorporate information on the home country's distance from the US from Mayer and Zignago (2011) ${ }^{24}$ and a dummy variable for whether English was an official language of the country.

To measure the strength of the home country's science base, we use the Scimago country rankings. ${ }^{25}$ For each country-year, Scimago creates a ranking based on the total number of published scientific articles. ${ }^{26}$ From this, we create 4 categories (ranked 1-20, 21-50, 51-100,100-250). We also separately control for the HC's total number of citations per article (Scimago), which turns out to have more statistical power in measuring the HC's scientific base.

\section{Results: The Location Decision}

Appendix Table 1 shows the average stay rates for those who were temporary residents at time of $\mathrm{PhD}$ and were working in the survey year (68.1\%). We can also measure (approximately) five-year stay rates in the survey of February 2010 (i.e. for those who received PhDs in March 2004 to January 2007) to be $69.5 \%$ percent, identical to Finn (2014)'s most recent five year stay rate estimate, for those who received PhDs in $2006 .{ }^{27}$ However, five-year stay rates in the October 2013 survey had risen to 71.5, yet

\footnotetext{
${ }^{22}$ We interpolate R\&D values for countries who only periodically report this number.

${ }^{23}$ We use POLITY2, the modified version of POLITY variable, converting the polity scores during wartimes (i.e. $66,-77$ and -88 ) to the lowest conventional polity scores (from -10 to 10). We also include a dummy variable for countries with no Polity score, mostly those from small island countries.

${ }^{24}$ The distance measure is calculated using the great circle formula, which uses the latitude and longitude of a country's most populous or capital city.

${ }^{25}$ Available at http://www.scimagojr.com/countryrank.php, accessed July 2017.

${ }^{26}$ Scimago also ranks fields within countries. We have also estimated our main equations using this ranking as well with qualitatively similar results, matching the NSF fields of study to the Scimago subject areas. There were about 800 missing values for this ranking, so we do not use this in the reported regressions.

${ }^{27}$ Our longer term stay rates are slightly lower than Finn's. In the sample used in this paper, $62.9 \%$ of those who graduated in 2001 were in the US in 2010 and $58.1 \%$ of those who graduated in 2003 were in the US in 2013. In contrast, Finn found that the 10 year stay rate for 2001-2011 was $65 \%$. Both studies refer to those who were temporary residents at time of doctorate receipt.
} 
fallen back to 66.2 in the February 2015 survey. ${ }^{28}$ Finally, we note that the NSF also estimated 5-year stay rates (NSF 2018) from the 2015 SDR, for temporary or permanent residents at PhD (and including those not working) at $70 \% .^{29}$

\section{The overall impact of the employment-based permanent visa cap on staying in the US}

Our regression analyses of the location decision are estimated as linear probability models and clustered by respondent (since $30 \%$ of people were surveyed more than once, see footnote 3 ). ${ }^{30}$ The unit of observation is person $i$ in survey year $t$ (where $t$ is 2010, 2013 or 2015). The dependent variable is an indicator variable for whether the person is currently working in the US.

The results begin in Table 1, which includes only the coefficients on the key variables. (coefficients on other explanatory variables for one specification are in Appendix Table 3). The first column of Table 1 does not include any visa policy variables, only control variables related to the individual and country-year. This and all regressions also include dummy variables for birth countries China and India, the two countries affected by the visa cap. We see that among STEM PhDs, ceteris paribus Chinese PhDs are 17.7 ppt. (percentage points) more likely and Indian PhDs are 10.6 ppt. more likely to remain in the US than those from all other countries combined (which we will abbreviate as RoW for Rest of World).

Were Chinese and Indian graduates discouraged from remaining in the US when the per-country limits on EB-2 visas became binding? To test this, we include in Table 1 Column 2 a dummy variable for whether the limits or caps on EB-2 visas were binding for that country during the month in which the person received his or her $\mathrm{PhD}$. This variable is highly significant $(\mathrm{t}=-4.86)$ and suggests that stay rates for those who were affected by binding caps were 7.90 lower than those who were not, ceteris paribus.

\footnotetext{
${ }^{28}$ However, we cannot know whether this drop in 2015 is a real drop or is due to the difference in the 2015 SDR sampling.

${ }^{29}$ Most of the difference between the NSF (2018) estimate and ours was due to the fact that they included permanent residents at $\mathrm{PhD}$, who clearly have higher stay rates. Also, those foreigners not working also had a higher stay rate.

${ }^{30}$ Results are robust to clustering by country (see Appendix Table 5, column 2).
} 
This regression assumes that the Chinese and Indians have the same reaction to an EB-2 visa application delay. Table 1 Column 3 includes separate dummies for the visa delay for India and China and indicates that the 7.90 ppt. coefficient was combining two significantly different $(t=1.99)$ effects, a decrease of 9.48 ppt. $(\mathrm{t}=-5.48)$ for students from China and a much smaller 3.89 ppt. $(\mathrm{t}=-1.43)$ decrease for students from India.

In Table 1 Column 4, we replace the EB-2 delay dummy with the moving average delay length (in years, see Figure 1), which is typically larger for India than for China and ranges from 1.6 years to 7.8 years and may be the cause of the disparate effects of the visa policy in these countries. Column 4 indicates that each additional year on average decreases the stay rate by 1.94 ppt. $(\mathrm{t}=5.3)$, so that a 2 year delay decreases it by around 4 ppt. but a 5 year delay decreases it by more than $9 \frac{1}{2}$ ppt. Column 5 divides the delay length variable into separate effects for China and India. These two coefficients on visa delay length are significantly different $(\mathrm{t}=2.22)$ : each year of delay decreased China's stay rates by $2.48 \mathrm{ppt}$. $(\mathrm{t}=-5.90)$ but only decreased India's stay rates by 1.21 ppt. $(\mathrm{t}=-2.39)$.

There are extremely large changes in visa delay times between Oct 2005 through June 2013 (the date of the last $\mathrm{PhD}$ conferred in our sample) - for India particularly and for China to a lesser extent (Figure 1). We therefore also, in Table 1 Column 6, estimate a more semiparametric model that replaces the linear visa delay variable with a set of dummies for each value for the number of years of delay length, rounded to the nearest year. For China, this includes 4 dummies ( 2 through 5 years) and, for India, 5 dummies (4 through 8 years).

For Chinese PhDs, all coefficients on the individual delay-length dummies are significantly different from zero (i.e. from no delay) and generally become more negative as the delay increases. In additional regressions, we added both the individual delay-year dummies and the two country-specific delay length variables simultaneously and used an F (Chow) tests to establish that for China, adding these additional delay dummies adds no explanatory power $(\mathrm{p}$-value $=0.467)$. Thus for China, a linear delay 
length variable is a sufficient statistic to capture the impact of EB-2 visa delays.

The pattern for India is different. In the Table 1 Column 6 semi-parametric model, we see that not all India delay dummies are significant. For the (relatively) shorter delays of 4 and 5 years, there is little impact on the stay rates of Indian students. For the longer run delays of 6, 7 and 8 years, there are large significant impacts on location, although the coefficients for 6,7 and 8 years of delay year are similar. An F (Chow) test rejects the hypothesis that adding the Indian annual delay dummies adds no explanatory power beyond a linear variable for the Indian delay length variable $(\mathrm{P}=0.044)$. However, the coefficients in Column 6 suggest a more parsimonious specification with a single dummy for long Indian visa delays (of more than $5 \frac{1}{2}$ years). We performed an additional test on a regression with the separate dummies and this single dummy for long Indian visa delays and found that the separate dummies do not add explanatory power $(\mathrm{p}$-value $=0.84)$. Therefore, in Column 7 we report the more compact model that is supported by these F tests - with a linear Chinese visa delay length variable and a dummy variable for long Indian visa delays ( $>51 / 2$ years).

We conclude that Chinese graduates respond consistently to each additional year of delay, but Indian PhDs only respond to very long delays. As Table 1 Column 7 shows, each year of visa delay decreases Chinese stay rates by 2.39 ppt., so that the longest delay they face during this period (of approximately 5 years) decreases the stay rate by approximately $12 \mathrm{ppt}$. In contrast, delays of more than around $5 \frac{1}{2}$ years decrease Indian stay rates by $8.89 \mathrm{ppt}$. (or on average $1.38 \mathrm{ppt}$. per delay year).

We have seen that every year of visa delay deters more Chinese from remaining in the US, but that only very long visa delays affect Indian PhDs. Why would there be a difference? We suggest some possible reasons, but have no definitive evidence to conclusively explain the differences.

One factor that may partially explain why Chinese $\mathrm{PhDs}$ appear more sensitive to visa delays is a difference in the tendency to marry American citizens. Family-based applications for permanent residency are not subject to quotas by nationality. According to the 2013 wave of the American 
Community Survey (ACS), 10.8\% of Indian-born PhDs (aged 25-50) in the US were married to an American citizen but only $2.8 \%$ of Chinese-born PhDs were. A second factor is the prevalence of firms with Indian headquarters among the largest employers of temporary H-1B positions (Mayda et al. 2018). Since most scientists remaining in the US outside of the nonprofit sector are likely to have an $\mathrm{H}-1 \mathrm{~B}$ visa (especially given the 2004 American Competitiveness Act which set aside 20,000 additional H-1B visas for those with advanced STEM degrees), Indians might have an advantage obtaining employment with these Indian-based firms. Finally, there may be more Chinese $\mathrm{PhD}$ recipients near the margin because, in some respects, China is a more attractive destination for recent $\mathrm{PhDs}$ than India. China has had faster GDP growth (20.7\% over the three years prior to $\mathrm{PhD}$ completion on average in contrast to $12.5 \%$ for India) and a higher GDP per capita (14.3\% of US GDP during our period vs. $7.5 \%$ for India), and China ranks higher on the Scimago country ranking of scientific journal articles (averaging 2.9 vs. 10.2 for India). This combined with a higher language barrier for Chinese students than for Indian students remaining in the US may make the net benefit of returning to China positive, even when wait times for permanent residency are shorter than wait times for Indian natives.

\section{Impacts on more permanent stay rates and reported intentions to stay}

The location observed immediately after $\mathrm{PhD}$ completion is often not a person's permanent location, but rather just the location of additional training as a postdoc or on OPT. In the Appendix, we assess the impact of the visa policy on more permanent location in several different models. Although the sample size is reduced and the significance levels of some coefficients are lower, the estimates shown in the Appendix demonstrate the robustness of the impact of visa restrictions on stay rates. For instance, in Appendix Table 4 Column 1, we exclude those within 3 years from $\mathrm{PhD}$ receipt or in postdocs and find that each year of EB-2 delay decreases longer-run Chinese stay rates by 2.14 ppt. See the Appendix for more discussion.

Prior research on stay rates has analyzed students' stated intentions to remain in the US, which 
may or may not be a good measure of actual stay rates. ${ }^{31} \mathrm{We}$ find that the effect of visa restrictions on reported intentions to stay in the US is weaker than the effect on actual stay rates (Appendix Table 4 Column 4.) For instance, we find a 0.93 ppt. per year decrease in intentions to stay for Chinese that falls to an insignificant 0.71 (Column 5) when we exclude postdocs; for Indians, we find an insignificant effect of long delays on intentions to stay in both columns. The small or insignificant effect of visas on intentions may reflect overconfidence among doctoral students about their ability to remain in the US; it may also reflect the fact that students remaining for postdocs do not need work visas (and can instead use OPT). Importantly, Appendix Table 4 Column 6 shows that the qualitative results for stay rates that we found in Table 1 are robust to controlling for stated intentions to remain in the US. These results and other columns of Appendix Table $\mathbf{4}$ are described in greater detail in the Appendix.

\section{Threats to Validity}

Earlier, we described several alternative possible reasons for our main results and mentioned the additional specifications we performed to test them. Here, we give more details about these tests.

There were no visa delays in the early years of our sample; after the quotas were reached (in Oct. 2005), visa delays increased over time - particularly for India (Fig 1). Are the coefficients on delay lengths simply picking up an increase in return rates over time for Indian and Chinese $\mathrm{PhDs}$ that is unrelated to visa delays? To test this, Table 2 Column 1 shows the compact model after including linear time trends for India and China (in addition to the standard non-country-specific $\mathrm{PhD}$ year fixed effects included in all regressions). Adding in these two country-specific time trends decreases the coefficient on the visa delay variables somewhat, but does not change the results substantially. For instance, comparing Table 2 Column 1 and Table 1 Column 7 compact models, the impact of a visa delay year on China is a bit lower (from -2.39 ppt. to -1.93 ppt., with a new t statistic of -2.58 ); similarly, the impact of a long visa 
delay on India is somewhat lower (it was previously -8.89 ppt., and is now -6.22 ppt., $\mathrm{t}=-2.13$ ). ${ }^{32}$

The second possible reason that China has a different pattern for later PhDs could be that we are picking up the effects of China's 1000 Talents Program, which began attracting younger STEM experts to return to China starting in 2011 (and older exceptional scientists since 2008). To test this, the regression in Table 2 Column 2, drops all Chinese observations from 2013 and 2015 surveys and also Chinese who were 40 or older in survey year 2010. Even with the few remaining Chinese in our analysis, we find no difference in the impact of the visa delay.

As an additional check of whether our results can be explained by trends in return rates seen in countries with similar characteristics, rather than the specific effects of US visa policy, we conduct placebo tests in which we assign students from Pakistan the EB-2 visa delay that applied to Indian students, and assign students from Taiwan the Chinese EB-2 visa delay. The logic is that students from these placebo countries will share many of the characteristics of students from China or India, but due to the smaller populations of Pakistan and Taiwan, there are fewer applicants for US EB-2 green cards and the per-country limits are never reached. Thus if we observe the same response to Indian and Chinese visa delays among students from placebo countries, it will suggest that our results are explained by factors other than US policy.

Table 2 Column 3 adds to the "compact regression" 33 a dummy for Pakistan, a dummy for Taiwan, and a placebo version of the visa delay variables giving Taiwan China's delay length and giving Pakistan a dummy for long Indian delays. In contrast to students from China who experienced a

\footnotetext{
32 The time trends are negative and only sometimes significant; however, we must remember that we have already also controlled for GDP per capita and scientific advancement. Improvements in these two home-country factors are likely to be the main factors that would increase return rates for reasons not related to visa delays. A less parametric test would instead include a complete set of $\mathrm{PhD}$-year fixed effects for India and for China respectively in addition to the current fixed effects for $\mathrm{PhD}$ year. However, in this model the visa delay coefficients will only be capturing the relatively small amount of month-to-month variation in moving averages of visa length within a year. Moreover, our choice of moving average period is itself arbitrary, so this should not be used to identify visa delay effects.

${ }^{33}$ See Table 2 Column 7. Note that results are similar using a semiparametric model as in Table 2 Column 6.
} 
significant decline in the stay rate of approximately 2.4 ppt. per year of additional visa delay, PhDs from Taiwan see a significant increase of approximately 3.3 ppt.; in contrast to India where long delays significantly decrease stay rates by 8.9 ppt., long delays significantly increase Pakistan's stay rates by an insignificant 9.1 ppt. Results are similar after dropping China and India from the sample (Table 2

Column 4). The fact that US visa policy with regard to China and India does not appear to have a deterrent effect on the stay rates of students from placebo countries is consistent with our story.

A final placebo test comes from the idea that, if our results are explained solely by the coincidentally increasing attractiveness of China and India over the period in which visa delays lengthened, we would expect all Chinese and Indian nationals to return at higher rates, and not just those who are temporary residents at the time of $\mathrm{PhD}$ receipt. To investigate this, we run the compact model on a sample of foreign-born STEM PhDs who were either permanent residents or naturalized citizens (Table 2 Column 5) at the time of $\mathrm{PhD}$. Consistent with our expectations, neither Chinese visa delay length nor the dummy for long Indian visa delays are significant. Results are similar in the semiparametric model (available upon request): the coefficients on the dummies for years of visa delay show no clear pattern and they are all statistically insignificant.

Additional robustness checks show that the results are robust to replacing the $\mathrm{PhD}$ year fixed effects with fixed effects for years from $\mathrm{PhD}$ (Appendix Table 5 Column 1). They are also robust to clustering errors by country of origin instead of by person (Appendix Table 5, Column 2) or adding country-specific fixed effects for the 18 additional countries of origin with at least 200 observations (Appendix Table 5, Column 3). Results were similar when we allowed China and India to have different coefficients in the different survey years to control for the possibility that the survey-year conditions in these countries were confounding factors (Appendix Table 5, Column 4); when we excluded the recession years 2007-2010 (Appendix Table 5, Column 5); and when we included the moving average 
of delays for those who had faced academic year 2001 caps (Appendix Table 5, Column 6). ${ }^{\mathbf{3 4}}$

\section{Results: How the EB-2 Visa Caps affect US Science}

\section{The STEM fields most affected}

The previous section shows that EB-2 caps directly affect US science by limiting the number of PhDs working in the US. And it is not surprising that the two countries with the most US-trained PhDs China and India - are also the ones for which the cap is binding. However, the per-country caps affect the US more - and we argue, more negatively - than an across-the-board EB-2 cap would. The number of American citizens obtaining PhDs in STEM fields overall is much smaller than the total number of UStrained STEM PhDs demanded by US employers. If every US citizen who received a US PhD in a STEM field between 2001 and 2013 and was employed in the survey years (2010, 2013 and 2015) worked in the US, they would only provide $67.8 \%$ of the demand for US-trained PhDs from those cohorts. ${ }^{35}$ Noncitizens are needed to fill this gap.

Even within STEM, Americans tend to study in different PhD STEM fields than citizens or those from other countries. This is obvious from Appendix Table 2. The third column shows that US citizens specialize in biological sciences and psychology which together account for $43 \%$ of their STEM PhDs (2001-2013 cohorts). Among US-educated biology PhDs in these cohorts working in the US, 71\% are American citizens; the similar figure for US-educated psychology PhDs is $93 \% .{ }^{36}$ On the other hand, Americans are much less likely to study electrical/computer engineering (only 3\% of STEM PhD recipients do) and American citizens fill only 30\% of US employment (of US-granted PhDs in the 2001-

\footnotetext{
${ }^{34}$ This robustness check is included out of an abundance of caution, despite knowing that recent legislation made the caps very temporary. See earlier discussion on Employment-Based Permanent Residency Visa Variables ${ }^{35}$ Not every one of these PhDs were in fact employed in the US, so that the proportion of US citizens-at-PhD among all employed US-granted 2001-13 PhD cohorts was only 65.1. Moreover, since the NSF data do not include PhDs trained in other countries working in the US, the actual cohort of all 2001-13-granted PhDs working in the US is considerably larger, and American citizens a much smaller proportion of this larger group.

${ }^{36}$ Not shown in table.
} 
2013 cohorts) in that field.

In Table 3 and illustrated in Figure 2, we define fields with excess demand as those in which American citizens could staff less than the $68.7 \%$ of current employment (of US-granted 2001-2013 PhDs). ${ }^{37}$ Excess demand fields include all engineering subfields, computer science, math/statistics, chemistry, physics, economics, and agricultural/food sciences. Americans provide only $48 \%$ of employment in these excess-demand fields, but $79 \%$ of employment in the remaining fields. International students provide the majority of employees (on average $52 \%$, with a maximum of $59 \%$ in Electrical/Computer Engineering) in these high-excess-demand fields.

Moreover, among international students, Indian and Chinese students exhibit patterns different from those from the rest of international students (Appendix Table 2, Table 3). 72\% of Chinese and 71\% of Indians received their PhDs in high-excess-demand fields, compared to $63 \%$ of non-citizens from the rest of the world (RoW). Together, Chinese and Indian students provide $28 \%$ of employment in excessdemand fields, with those from other countries providing the additional $24 \%$. In contrast, PhDs from India and China represent about 9\% of employment in other fields (and the rest of the world represents $12 \%)$.

The high-demand fields also tend to have higher average salaries, as seen in Table 3. Perhaps not surprisingly, fields with high US salaries have higher average stay rates as well (Table 3). The countries that send large numbers of students to be trained in fields with high excess demand in the US will thus tend to have high stay rates in the US, and are therefore are at more risk of being capped by a per-country visa limit. Consequently, a policy that caps Chinese and Indian permanent residency visas will limit the supply of skills in the fields most needed by US employers of STEM PhDs.

The effects of this policy on the US economy stand in stark contrast to the impact of a different

\footnotetext{
${ }^{37}$ As noted above, this is the average share of employment (of these cohorts) that could be staffed by Americans across all fields. However, exactly the same fields are categorized as excess-demand whether we use this percentage or the average percentage of American citizens among US STEM employment (of these cohorts), 65.1\%.
} 
policy that also reduces the stay rates of international students, that is, J-1 visas for educational exchange. These visas require graduates to return to their home country for 2 years, and many of the STEM PhD students who receive financial support from their home country governments either have J-1 visas, or have funding from specific programs in foreign countries that also stipulate that students return to the home country after completing their studies. Appendix Table 1 indicates that about 4\% of US-trained foreign PhDs received support from foreign governments during graduate school. Ceteris paribus, receiving foreign support is associated with approximately a $33 \mathrm{ppt}$. decrease in the probability of staying in the US (Appendix Table 3) and a 34 ppt. increase in the likelihood of returning to the home country (Table 4 columns 1 and 2),. However, those with foreign government support are concentrated in fields of study characterized by country-specific human capital. These fields include agricultural and food sciences, environmental sciences, and social sciences such as psychology and political science. These are all fields with relatively low excess demand, and also lower-than-median US salaries. ${ }^{38}$

It is possible, however, that the visa delays may have different impacts on Indians/Chinese from different fields. One possibility is that those least affected by the cap are those in high-excess-demand fields because they obtain larger net benefits from staying, including higher salaries, and employers are more willing to commit to an EB-2 process that can take many years. To test this, in Appendix Table 5 Column 7 we have re-estimated our compact regression adding in interactions between the visa delay variables and a dummy for high excess-demand fields. We found that visa delays impact stay rates in both excess-demand fields and others, and that for neither China nor India is there a significantly different impact of visa delays between high excess-demand fields and other fields. Numerically, the visa delay's impact is slightly smaller for high-excess-demand fields: For China, impact of a year of delay is 2.25 in high-demand fields v. 2.76. For India, the impact of a long delay is 8.55 v. 9.60. We conclude that the

\footnotetext{
${ }^{38}$ The exception is agricultural and food science, which is categorized as excess demand by my definition (i.e. Americans could only fill $61 \%$ of US employment in this field. However, it does have a low stay rate $(50 \%)$ and salaries far below the median.
} 
visa cap has effects on both high-excess-demand fields and other fields.

Similarly, it may be that the visa delays only affect students of "lesser ability" (once again, because the net benefits of staying are lower). Our best measure of inherent ability is the rank of the $\mathrm{PhD}$ institution. Overall, staying in the US is not correlated with the $\mathrm{PhD}$ rank ceteris paribus. ${ }^{39}$ Thus, in the control variable coefficients in Appendix Table 3, no institutional rank category coefficient is significantly different from the top (excluded) rank, nor from each other.

Nevertheless, it is possible that the impact of visa restrictions on Chinese and Indian students depends on their ability as proxied by the rank of their PhD institutions. To test this, in Appendix Table 5

Column 8, we add controls for institution rank dummies (simplified into 3 equally-sized categories) interacted with dummies for China and India and interactions between these dummies and a dummy for having the visas capped, separately for India and China. For both China and India, none of the visa interactions are significant. That is, the visa seems to have affected all ranks similarly. ${ }^{40}$

\section{Visa delays and type of job and salaries}

There are no limits on the number of EB-2 visas that can be granted to employees of universities and other non-profits. Therefore, we might expect that once EB-2 caps became binding, Indians and Chinese would have become more likely to move to academia or other nonprofit jobs. Prior research (Amuedo-Dorantes and Furtado 2017) has shown that constraints on H-1B visas for certain countries may lead those affected by the constraints to take jobs in the academic sector rather than industry, since academic institutions are also exempt from the H-1B quotas. To test this for EB-2 visas, we ran regressions in which the dependent variable is a dummy equal to 1 if the respondent is employed in

\footnotetext{
${ }^{39}$ This is a similar finding to Brentschneider and Dai (2017). Interestingly, we find that intentions to stay are correlated with institutional rank. In our regressions of these intentions, we find that people from top 10 schools are about 6.9 ppt. more likely to intend to remain in the US than those from worse ranks, 8.5 ppt. more likely than those from unranked schools.

${ }^{40}$ Note however, in coefficients not shown, that for China - but not India or the rest of the world - those from highly ranked schools are less likely to remain in the US. Our results contrast with Kato and Sparber's (2013) findings that H-1B visa limitations keep the best undergraduates from even applying to US colleges.
} 
academia, restricting the sample to people employed in the US but not employed in a post-doc ${ }^{41}$ (Column 5 of Table 4), with the same right-hand-side variables as in the compact model. The results showed no impact of the visas on working in academia. ${ }^{42}$ Alternatively, in Column 6 of Table 4, we included those employed in a postdoc. Again the coefficients on the visa variables again are not statistically significant at standard levels. There is a hint that long Indian delays may increase choosing academia (including academic postdocs), but the t-statistic of this coefficient is only $1.54(\mathrm{p}=0.123){ }^{43}$

We also analyzed whether visa policy increases employment in the broader group of all nonprofits (academia + nonprofits), without and with current postdocs included (Columns 7 and 8 of Table 4). The visa delay coefficients were not statistically significant for either country or sample. However, once again, there is a hint that the long caps on Indians increased their likelihood of working for the broad not-for-profit sector including postdocs, since the coefficient on long Indian caps is 6.0 ppt. with $\mathrm{t}=1.71(\mathrm{p}=.087)$. We conclude that in terms of long run jobs (post-postdoc), the visa is not pushing people into academia besides postdocs; however, it may be encouraging Indians to enter postdocs. Note that in more detailed analysis, Amuedo-Dorantes and Furtado also find that the H-1B visa changes they study increase academic employment for holders of Masters degrees but not for holders of PhDs.

Why didn't the visas not encourage a shift towards academic employment? One potential explanation is that $\mathrm{PhD}$ scientists have very strong preferences for either a job in academia or in industry and these preferences dominate the effects of permanent residency delays. Another potential explanation is that those hired into academia would be inframarginal with or without any visa delays.

Visa delays also can affect how long the potential immigrant stays with a firm, since leaving

\footnotetext{
${ }^{41}$ Post-docs are covered by student visas or OPT.

${ }^{42}$ We tried various different definitions of academic jobs from the narrow "tenure track academic jobs" to the broadest "any job in the education sector" (shown in Table 4), with similar results. Regression results available from the authors.

${ }^{43} \mathrm{We}$ also estimated this as a semiparametric model and no single delay coefficient was significant, with changing signs.
} 
means losing their place on the EB-2 queue. This precludes the scientists from starting their own companies, and typically also precludes them from working in new small companies (Roach, Sauermann and Skrentny 2018). To test these possibilities, we ran regression analyses of the probability of being "self-employed,", "self-employed incorporated,", or "works for small new firms"44 (respectively) of those working in the US. The visa delay variables were not even marginally significant in any of these regressions. We note that, in general, few $\mathrm{PhDs}$ are in these firms, making it difficult to unearth any significant effects in our limited samples (See Appendix Table 1b). Along the same lines, we test and do not find that visa delays affect the size of the firm of those working in the US private sector. We also do not estimate any significant impacts of visa delays on the length of time they had been with their current firm (for those working in the US private sector).

Table 5 first demonstrates that graduates affected by visa restrictions are significantly more likely to be temporary residents ceteris paribus than unaffected students $(7.5 \%$ for Indian graduates facing long visa delays and 1.4\% per year for Chinese graduates, Table 5 Column 1). This could in principle lead to lower salaries all else equal, since workers waiting for permanent residency may be less prone to being hired by competing employers. Indeed, if we run a regression of log salary (of those working in the US) on control variables plus temporary resident status, we find that ceteris paribus temporary residents earn 5.0\% less. (Table 5 Column 2). However, when we run log salary regressions with our visa delay variables replacing the temporary resident indicator, neither visa delay coefficient is significant. (Table 5 Column 3). We can reconcile these two findings by speculating that the temporary residency accompanying visa delays is associated with lower salaries, but that there must be some positive selection, so that the Chinese and Indians who are not deterred from staying in the US by the visa delays are the ones being offered higher salaries than the ones who are deterred.

\footnotetext{
${ }^{44}$ Firms with less than 25 employees that came into being within the past 5 years. All regression results available from the authors.
} 


\section{Results: How the EB-2 Visa Caps affect Home Countries}

\section{Are they going home?}

The first columns of Table 4 look at whether visa delays are associated with increased propensity to locate in home countries or in third countries which are neither home nor the US. It shows that STEM graduates who leave the US due to visa delays are almost all returning to the home country. Thus, long visa delays for India are associated with an increase of $8.1 \mathrm{ppt}$. in the probability of returning home ( $\mathrm{t}=$ 3.63; compare to a reduction of $-8.9 \mathrm{ppt}$. for staying in the US), while each year of delay increases the probability of returning to China by 2.08 ppt. ( $\mathrm{t}=5.91$, compare to a -2.39 effect on staying in the US). Looking at the semiparametric model with separate dummies for each number of years of delay in Column 2, we see that the significant visa effects for Indians returning home begin at visa lengths of 5 years with a coefficient of 5.06 ppt. (significant at the $5 \%$ level), whereas the impact on staying in the US only began at 6 years (rounded).

However, we observe no significant effects of visa delays on the probability of being located in a third country (Table 4 Columns 3 and 4 ).

\section{How much do Stay and Return Rates depend on the Science Base in the Home Country?}

An additional dimension of EB-2 delays' impacts on the US economy lies in the relationship between the home country's scientific advancement and macroeconomic conditions and stay and return rates.

Coming from a home country with a very weak science base - as measured using Scimago's country rankings of publications - increases stay rates. Similarly it decreases return rates. Specifically, in our regression results (Appendix Table 3), while there are no significant differences in stay rates between the top 20 countries (in terms of publications) and the next 30, home countries with worse (higher than 50) Scimago rankings are associated with an increase in the US stay rate (9.2 ppt. more than the top 
ranks) and with a decrease in the home country return rates (approximately $10.6 \mathrm{ppt}$. lower ${ }^{45}$ ). Note that fully $89 \%$ of the sample come from countries ranked 50 or better. Thus the strong effect on stay rates of being from a particularly weak science countries applies to a relatively small number of graduates.

The Scimago country rankings calculations are based on the total number of publications in the country, which favors high population countries like China and India (ranked $2^{\text {nd }}$ and $7^{\text {th }}$ respectively in 2013). We therefore have computed an alternative measure using Scimago data, the log of citations per article in the scientist's field in the home country (in the year leading to the $\mathrm{PhD}$ ). This variable has a very significant coefficient: each $1 \%$ increase in citations per article decreases the likelihood of staying in the US by approximately 0.16 ppt. (Appendix Table 3) ${ }^{46}$ and increases the likelihood of returning home by almost $0.13 \mathrm{ppt}$.

Holding these science variables constant, R\&D spending as a percentage of GDP at the time of $\mathrm{PhD}$ is not significantly associated with stay rates or with return rates holding. The coefficient on the dummy for the $3.4 \%$ of observations missing home-country R\&D percentage does not affect stay rates, but those countries with missing $\mathrm{R} \& \mathrm{D}$ figures have more than $5 \mathrm{ppt}$. lower return rates ceteris paribus.

Just as we asked whether the visa delay effects differ by field type and by $\mathrm{PhD}$ institution rank, we also want to know whether responses to EB-2 visa delays depend on the strength of science in the home country. To investigate this, we exploit the fact that the scientific changes in China and India did not occur evenly across fields. We created interaction terms between field-specific publication rankings from the Scimago data for India and China and the visa variables in the compact model. (Appendix Table 5 Column 9). Adding these to the stay rate regressions, the effect of the visa does not depend on the scientific level of the field in either country.

\section{How much do the Stay and Return Rates depend on Macroeconomic Conditions at Home?}

\footnotetext{
${ }^{45}$ All home country coefficients are available from the authors.

${ }^{46}$ The impact is larger -0.19 ppt. - when separate controls for the high science countries China and India are excluded from the regression.
} 
How will stay rates change as economic conditions improve in home countries? To estimate this, we first consider the impact of macroeconomic conditions around the time of $\mathrm{PhD}$. While Grogger and Hanson (2015) found larger and significant effects on intentions to stay, we find an insignificant relationship between the GDP per capita in the home country at time of $\mathrm{PhD}$ relative to the US and stay rates (e.g. in Appendix Table 3 the coefficient is $-0.017, \mathrm{t}=-0.58$. ${ }^{47}$ Similarly, there is no effect of relative GDP per capita on location in the home country $(\mathrm{t}=1.10)$. We also experimented with alternative GDP measures, including the growth rate of home country per capita GDP leading up to the PhD (relative to the US growth and also a dummy variable for particularly high GDP per capita growth rates (above $10 \%$ per year). ${ }^{48}$ None were significant.

However, in our regressions of intentions to stay in the US from the SED - the measure used by Grogger and Hanson - the relative GDP per capita was significant (with more home country relative GDP growth decreasing intentions to stay by approximately 9.71 ppt. ( $t=-3.23$ based on the "compact" specification of Appendix Table 4 Column 6) $)^{49}$ even with all the science variable controls.

The reason that GDP does not impact actual location - as we would have expected - is that we are simultaneously controlling for the science base of the home country. In results which exclude our measures of a country's science base (country rank, citations per article discussed below), the coefficient on (relative) GDP per capita in the PhD year becomes large - on the order of $-9.8 \%$ - and highly significant ( $\mathrm{t}=-4.02$, from the regression of Appendix Table 5, Column 10). The impact of GDP per capita on return rates when the science variables are excluded is also large and highly significant (6.8 ppt. $\mathrm{t}=3.33$ ). We conclude that GDP per capita is highly correlated with the strength of science in the country,

\footnotetext{
${ }^{47}$ Note that the GDP measure is relative to the US GDP, both adjusted for PPP.

${ }^{48}$ Results from these alternative regressions are available on request from the authors. We add this dummy because countries with extremely high growth rates (above the $90^{\text {th }}$ percentile in our sample) may behave differently from others.

${ }^{49}$ Excluding postdocs as in Appendix Table 5, Column 10, the coefficient of relative GDP on intentions is still large and significant: $-7.9 \mathrm{t}=-2.2$
} 
and it is these science measures that are the most important home country characteristics determining location. ${ }^{50}$

\section{Conclusion}

American firms and universities rely heavily on foreign-born doctoral recipients to fill research positions in most STEM fields. In fields like computer science and electrical/computer engineering, a large share of employees come from China and India. Despite the fact that degree-holders earn particularly high salaries, relatively few American citizens enroll in these fields. At the same time, US immigration policy limits the number of permanent residency visas that can be granted to nationals of a particular country, a policy which affects China and India but not other countries.

This paper demonstrates that US visa policy differentially constrains the supply of highly skilled workers in precisely the fields of study that are in greatest demand by US firms, universities, and research organizations, fields where Indians and Chinese are concentrated. Country-based limits on EB-2 green cards are associated with reductions in the stay rates of Chinese students of 2.4 percentage points ( $p p t$.) per year of delay relative to students from the rest of the world, while Indian students are only affected by very long delays in visa processing. Indian students facing delays of $51 / 2$ years or more have a relative stay rate that is about 8.9 ppt. lower. At the same time, our results show that students from countries with greater scientific output have lower stay rates. This suggests not only that the current approach to allocating permanent residency visas reduces the supply of highly skilled STEM workers, but also that as support for science continues to improve in sending countries such as China, the negative effects of visa delays in the US will only intensify. These results suggest that a policy that factored in the demand for

\footnotetext{
${ }^{50}$ We also reran the base compact model (Table 2 column 7) controlling for the relative home country GDP per capita measure in the year preceding the survey year instead of the $\mathrm{PhD}$ year and found qualitatively similar results an insignificant effect of relative GDP per capita when country's science strength is controlled for, but a large, significantly negative coefficient on relative GDP per capita in the $\mathrm{PhD}$ year when controls for science base are excluded,
} 
skilled workers when allocating permanent residency visas would generate better innovation outcomes for the US than a policy with country quotas. 


\section{References}

The American Competitiveness in the 21st Century Act (AC21), Pub. L. 106-313 (October 17, 2000), 114 Stat. 1251.

Amuedo-Dorantes, Catalina and Delia Furtado (2017). "Settling for Academia? H-1B Visas and the Career Choices of International Students in the United States," Journal of Human Resources December 5, 2017 0816-8167r1

Arlington, VA (NSF 13-300) [September 2012] https://www.nsf.gov/statistics/infbrief/nsf13300/ (accessed 12/30/2017).

Argueta, Carla (2016), "Numerical Limits on Permanent Employment-Based Immigration: Analysis of the Per-country Ceilings" Congressional Research Service Report 7-5700, www.crs.gov

Bratsberg, Bernt (1995). The Incidence of Non-Return Among Foreign Students in the United States. Economics of Education Review 14(4) 373-384.

Borjas, George and Bernt Bratsberg (1996) "The Outmigration of the Foreign-born." Review of Economics and Statistics 78(1). 165-175.

Brentschneider, Stuart and Yiqun Dai (2017), "Why do foreign citizens with US Ph.D. Degrees return home?," Working Paper.

Breschi, Stefano, Francesco Lissoni, Ernest Miguelez (2018), "Return migrants' self-selection: Evidence for Indian inventors," NBER working paper No. 24809

Depew, Briggs, Peter Norlander and Todd A. Sorensen (2017). "Interfirm-Mobility and return migration patterns of skilled guest workers." Journal of Population Economics 30, 681-721. DOI 10.1007/s00148-016-0607-y

Feenstra, Robert C , Robert Inklaar, and Marcel P. Timmer (2015), "The Next Generation of the Penn World Table," American Economic Review, 105(10): 3150-3182.

Finn, Michael (2014) “Stay Rates of Foreign Doctorate Recipients from U.S. Universities, 2011," Oak Ridge Institute for Science and Education working paper, https://pdfs.semanticscholar.org/7a4c/49e7878730b587201548338aa6052e2401b7.pdf (accessed $12 / 30 / 2017)$

Ganguli, Ina and Patrick Gaule (2018), "Will the U.S. Keep the Best and the Brightest (as Postdocs)? Career and Location Preferences of Foreign STEM PhDs," NBER Working Paper No. 24838.

Grogger, Jeffrey, and Gordon H. Hanson (2015), “Attracting Talent: Location Choices of Foreign-Born PhDs in the United States" Journal of Labor Economics, 33(S1), pp. S5-S38.

Hunt, Jennifer, and Marjolaine Gauthier-Loiselle. 2010. "How Much Does Immigration Boost Innovation?" American Economic Journal: Macroeconomics, 2 (2): 31-56. 
Hunt, Jennifer (2017), "How Restricted is the Job Mobility of Skilled Temporary Work Visa Holders?” NBER Working Paper No. 23529. June 2017.

Kahn, Shulamit and Megan J. MacGarvie (2016a), "How Important Is U.S. Location for Research in Science?" The Review of Economics and Statistics, 98:2, 397-414.

Kahn, S. and MacGarvie, M. (2016b) "Do return requirements increase international knowledge diffusion? Evidence from the Fulbright program. ” Research Policy, 45(6) July 2016: pp.1304-1322.

Kato, Takao and Chad Sparber (2013) "Quotas and Quality: The Effect of H-1B Visa Restrictions on the Pool of Prospective Undergraduate Students from Abroad." Review of Economics and Statistics 95(1) $109-126$.

Khosla, Pooja. (2018) Wait time for permanent residency and the retention of immigrant doctoral recipients in the U.S. Economic Analysis and Policy, 57, 33-43.

Marshall, Monty, and Keith Jaggers (2002), The Polity IV Project: Political regime characteristics and transitions. University of Maryland.

Mayer, Thierry and Soledad Zignago (2011), "Notes on CEPII's distances measures: The GeoDist database" CEPII Working Paper no. 2011-25, December.

National Science Foundation (2018), National Center for Science and Engineering Statistics. Science and Engineering Indicators 2018. https://www.nsf.gov/statistics/2018/nsb20181/report

Roach, Michael, Henry Sauermann and John Skrentny (forthcoming). Entrepreneurial Characteristics, Preferences and Outcome of Native and Foreign Science \& Engineering PhD Students." In Ina Ganguli, Shulamit Kahn and Megan MacGarvie eds. The Role of Immigrants and Foreign Students in Science, Innovation and Entrepreneurship. Cambridge MA: NBER.

Soon, Jan-Jan (2008) “The determinants of international students' return intention,” University of Otago Economics Discussion Paper No. 0806.

Stuen, Erik T., Ahmed Mushfiq Mobarak, Keith E. Maskus (2012), "Skilled Immigration and Innovation: Evidence from Enrolment Fluctuations in US Doctoral Programmes," The Economic Journal, Volume 122, Issue 565, Pages 1143-1176

Zeithammer, Robert and Ryan P. Kellogg (2013), "The Hesitant Hai Gui: Return-Migration Preferences of U.S.-Educated Chinese Scientists and Engineers," Journal of Marketing Research: October 2013, Vol. 50, No. 5, pp. 644-663. 


\section{Figure 1}

Expected wait time by $\mathrm{PhD}$ completion date, actual and moving average

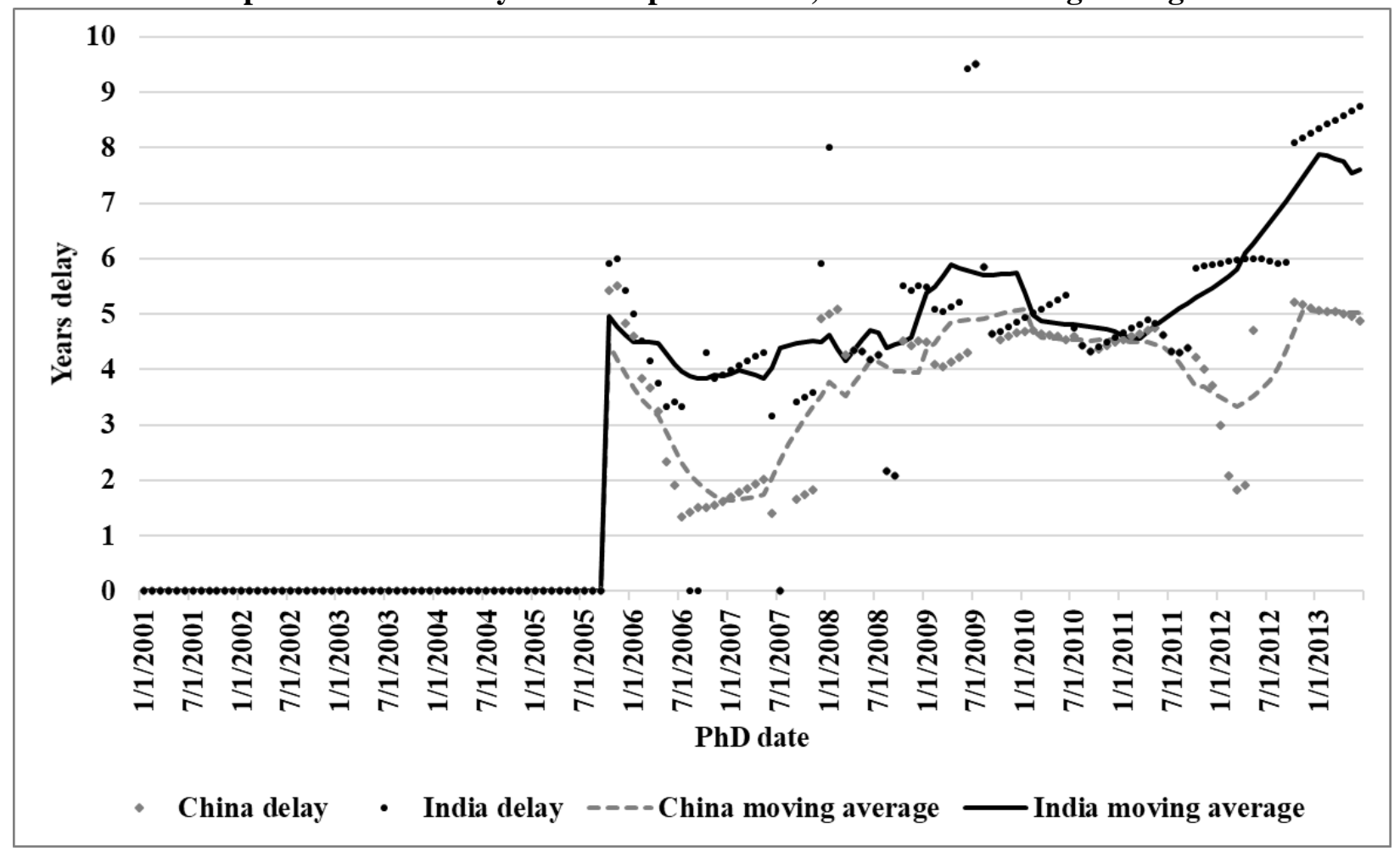


Figure 2 Distribution of Employed US PhDs (cohorts 2001-13)

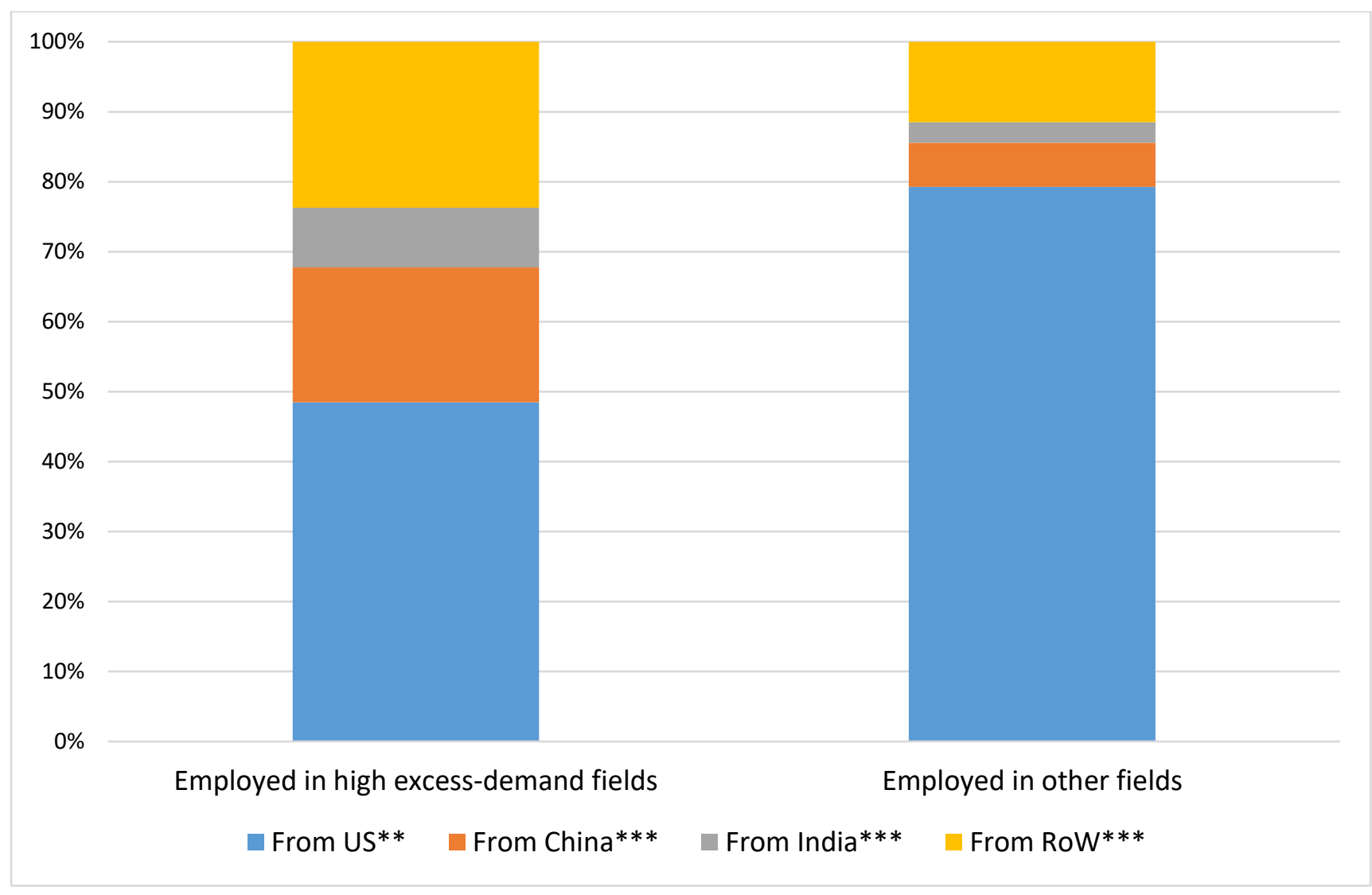

* Excess-demand fields have \% US citizens among US-trained $\mathrm{PhDs}<65 \%$ total employed ** US-born and naturalized citizens

*** Population includes temporary and permanent residents at $\mathrm{PhD}$ from these countries. RoW Rest of World 
Table 1: OLS Regressions

Dependent variable: Staying in the US

Population: International students (temporary residents at $\mathrm{PhD}$ )

\begin{tabular}{|c|c|c|c|c|c|c|c|}
\hline & (1) & (2) & (3) & (4) & (5) & (6) & (7) \\
\hline EB-2 cap binding & & $\begin{array}{c}-0.079 * * * \\
(0.016)\end{array}$ & & & & & \\
\hline India $\mathrm{X}$ cap binding & & & $\begin{array}{l}-0.039 \\
(0.027)\end{array}$ & & & & \\
\hline China $X$ cap binding & & & $\begin{array}{c}-0.095^{* * *} \\
(0.017)\end{array}$ & & & & \\
\hline EB-2 delay & & & & $\begin{array}{c}-0.019 * * * \\
(0.004)\end{array}$ & & & \\
\hline India $X$ delay & & & & & $\begin{array}{l}-0.012^{*} \\
(0.005)\end{array}$ & & \\
\hline China X delay & & & & & $\begin{array}{c}-0.025^{* * *} \\
(0.004)\end{array}$ & & $\begin{array}{c}-0.024 * * * \\
(0.004)\end{array}$ \\
\hline India X 4 yr. delay & & & & & & $\begin{array}{l}-0.016 \\
(0.032)\end{array}$ & \\
\hline India X 5 yr. delay & & & & & & $\begin{array}{l}-0.029 \\
(0.030)\end{array}$ & \\
\hline India X 6 yr. delay & & & & & & $\begin{array}{l}-0.095^{*} \\
(0.039)\end{array}$ & \\
\hline India $X 7$ yr. delay & & & & & & $\begin{array}{l}-0.127^{*} \\
(0.056)\end{array}$ & \\
\hline India $X 8$ yr. delay & & & & & & $\begin{array}{l}-0.128^{*} \\
(0.057)\end{array}$ & \\
\hline China X 2 yr. delay & & & & & & $\begin{array}{l}-0.064^{*} \\
(0.029)\end{array}$ & \\
\hline China X 3 yr. delay & & & & & & $\begin{array}{c}-0.102 * * * \\
(0.029)\end{array}$ & \\
\hline China $\mathrm{X} 4$ yr. delay & & & & & & $\begin{array}{c}-0.085^{* * *} \\
(0.019)\end{array}$ & \\
\hline China X 5 yr. delay & & & & & & $\begin{array}{c}-0.131 * * * \\
(0.023)\end{array}$ & \\
\hline India $\mathrm{X}$ long delay & & & & & & & $\begin{array}{c}-0.089 * * * \\
(0.027)\end{array}$ \\
\hline India & $\begin{array}{c}0.106 * * * \\
(0.031)\end{array}$ & $\begin{array}{c}0.164 * * * \\
(0.033)\end{array}$ & $\begin{array}{c}0.136 * * * \\
(0.037)\end{array}$ & $\begin{array}{c}0.175^{* * *} \\
(0.034)\end{array}$ & $\begin{array}{c}0.152 * * * \\
(0.036)\end{array}$ & $\begin{array}{c}0.137 * * * \\
(0.037)\end{array}$ & $\begin{array}{c}0.123^{* * *} \\
(0.031)\end{array}$ \\
\hline China & $\begin{array}{c}0.177 * * * \\
(0.030) \\
\end{array}$ & $\begin{array}{c}0.229 * * * \\
(0.032)\end{array}$ & $\begin{array}{c}0.238^{* * * *} \\
(0.032) \\
\end{array}$ & $\begin{array}{c}0.223 * * * \\
(0.032) \\
\end{array}$ & $\begin{array}{c}0.236 * * * \\
(0.032) \\
\end{array}$ & $\begin{array}{c}0.238^{* * *} \\
(0.033) \\
\end{array}$ & $\begin{array}{c}0.232 * * * \\
(0.032) \\
\end{array}$ \\
\hline R-squared & 0.205 & 0.207 & 0.207 & 0.207 & 0.208 & 0.208 & 0.208 \\
\hline
\end{tabular}


Table 2: Robustness and placebo tests

Dependent variable: Staying in the US
(1)
(2)
(3)
(4)
(5)

\begin{tabular}{|c|c|c|c|c|c|}
\hline & $\begin{array}{c}\text { Linear time } \\
\text { trend }\end{array}$ & $\begin{array}{c}\text { Thousand } \\
\text { Talents }\end{array}$ & \multicolumn{3}{|c|}{ Placebo } \\
\hline India X long delay & $\begin{array}{l}-0.062^{*} \\
(0.029)\end{array}$ & $\begin{array}{c}-0.091^{* * *} \\
(0.027)\end{array}$ & $\begin{array}{c}-0.083^{* *} \\
(0.027)\end{array}$ & & $\begin{array}{l}-0.004 \\
(0.028)\end{array}$ \\
\hline China $\mathrm{X}$ delay & $\begin{array}{c}-0.019^{*} \\
(0.008)\end{array}$ & $\begin{array}{c}-0.025^{* * *} \\
(0.007)\end{array}$ & $\begin{array}{c}-0.022 * * * \\
(0.004)\end{array}$ & & $\begin{array}{l}-0.006 \\
(0.005)\end{array}$ \\
\hline India X PhD year & $\begin{array}{l}-0.008^{*} \\
(0.004)\end{array}$ & & & & \\
\hline China $\mathrm{X} \mathrm{PhD} \mathrm{year}$ & $\begin{array}{l}-0.005 \\
(0.005)\end{array}$ & & & & \\
\hline India & $\begin{array}{c}0.178 * * * \\
(0.043)\end{array}$ & $\begin{array}{c}0.116^{* * *} \\
(0.031)\end{array}$ & $\begin{array}{c}0.124 * * * \\
(0.033)\end{array}$ & & $\begin{array}{c}0.006 \\
(0.032)\end{array}$ \\
\hline China & $\begin{array}{c}0.254 * * * \\
(0.038)\end{array}$ & $\begin{array}{c}0.222 * * * \\
(0.035)\end{array}$ & $\begin{array}{c}0.225^{* * *} \\
(0.033)\end{array}$ & & $\begin{array}{l}-0.003 \\
(0.033)\end{array}$ \\
\hline Pakistan & & & $\begin{array}{l}0.018 \\
(0.066)\end{array}$ & $\begin{array}{c}0.012 \\
(0.067)\end{array}$ & \\
\hline Taiwan & & & $\begin{array}{r}-0.076^{*} \\
(0.037)\end{array}$ & $\begin{array}{l}-0.071 \\
(0.037)\end{array}$ & \\
\hline Pakistan - delay & & & $\begin{array}{l}0.091 \\
(0.129)\end{array}$ & $\begin{array}{c}0.084 \\
(0.127)\end{array}$ & \\
\hline Taiwan - delay & & & $\begin{array}{r}0.033^{* *} \\
(0.011) \\
\end{array}$ & $\begin{array}{r}0.030^{* *} \\
(0.011) \\
\end{array}$ & \\
\hline R-squared & 0.207 & 0.189 & 0.209 & 0.13 & 0.045 \\
\hline \# observations & 22,470 & 18,211 & 22,470 & 14,858 & 5,746 \\
\hline
\end{tabular}

$* \mathrm{p}<0.05, * * \mathrm{p}<0.01, * * * \mathrm{p}<0.001$. Robust standard errors, clustered by respondent, in parentheses. All regressions include fixed effects for survey year, year of $\mathrm{PhD}$, and 2-digit field of study. See note on Table 2 for additional controls. Column 1 includes a linear time trend interacted with the China and India dummies. To control for the effects of the Thousand Talents program, column 2 excludes observations from survey years 2013 and 2015 for Chinese scientists who were 40 or older in 2010. Columns 3 and 4 contain results of a placebo test using students from Taiwan and Pakistan. Column 5 contains results of a placebo test using students who were already permanent residents at time of $\mathrm{PhD}$. 


\section{Table 3: Characteristics of High Excess Demand Fields*}

In excess-demand fields In other fields Total

US Employment of US-granted PhDs (cohorts 2001-2013)

\begin{tabular}{|c|c|c|c|}
\hline Total & $45.95 \%$ & $54.05 \%$ & $100.00 \%$ \\
\hline \multicolumn{4}{|l|}{ By country of origin } \\
\hline From US** & $48.49 \%$ & $79.29 \%$ & $65.14 \%$ \\
\hline From China $* * *$ & $19.28 \%$ & $6.30 \%$ & $12.27 \%$ \\
\hline From India*** & $8.52 \%$ & $2.90 \%$ & $5.48 \%$ \\
\hline From $\operatorname{RoW}^{* * *}$ & $23.71 \%$ & $11.51 \%$ & $17.11 \%$ \\
\hline Total & $100 \%$ & $100 \%$ & $100 \%$ \\
\hline
\end{tabular}

Average salary

$\$ 104,260 \quad \$ 81,169 \quad \$ 91,799$

US PhDs Granted 2001-2013

\begin{tabular}{llll}
\hline Total & $47.59 \%$ & $52.41 \%$ & $100 \%$
\end{tabular}

By country of origin

$\begin{array}{cccc}\text { From US** } & 34.05 \% & 65.95 \% & 100 \% \\ \text { From China*** } & 72.18 \% & 27.82 \% & 100 \% \\ \text { From India*** } & 71.38 \% & 28.62 \% & 100 \% \\ \text { From RoW*** } & 62.77 \% & 37.23 \% & 100 \%\end{array}$

Average stay rate of temp. resident $\mathrm{PhDs}$

$69.83 \% \quad 64.42 \% \quad 68.16 \%$

* We define fields with excess demand as those in which American citizens could staff less than the $68.7 \%$ of current employment (of US-granted 2001-2013 PhDs). 68.7\% is the average share of employment that could be staffed by Americans across all fields. 


\section{Table 4: Geographic and Sectoral Destinations of Graduates}

\begin{tabular}{|c|c|c|c|c|c|c|c|c|}
\hline & (1) & (2) & (3) & (4) & (5) & (6) & (7) & (8) \\
\hline & \multicolumn{4}{|c|}{ Population: all Temp. Residents at PhD } & \multicolumn{4}{|c|}{ Population: Temp. Residents at $\mathrm{PhD}$ working in US } \\
\hline & $\begin{array}{l}\text { home } \\
\text { country }\end{array}$ & & $\begin{array}{l}\text { third } \\
\text { country }\end{array}$ & & $\begin{array}{l}\text { academia } \\
\text { (excl. } \\
\text { postdocs) }\end{array}$ & $\begin{array}{l}\text { academia } \\
\text { (incl. } \\
\text { postdocs) }\end{array}$ & $\begin{array}{l}\text { non-profit } \\
\text { (excl } \\
\text { postdocs) }\end{array}$ & $\begin{array}{l}\text { non-profit } \\
\text { (incl } \\
\text { postdocs) }\end{array}$ \\
\hline India $\mathrm{X}$ long delay & $\begin{array}{c}0.081 * * * \\
(0.022)\end{array}$ & & $\begin{array}{c}0.008 \\
(0.016)\end{array}$ & & $\begin{array}{c}0.031 \\
(0.043)\end{array}$ & $\begin{array}{c}0.055 \\
(0.036)\end{array}$ & $\begin{array}{c}0.038 \\
(0.044)\end{array}$ & $\begin{array}{c}0.060 \\
(0.035)\end{array}$ \\
\hline China $X$ delay & $\begin{array}{c}0.021^{* * *} \\
(0.004)\end{array}$ & & $\begin{array}{c}0.003 \\
(0.003)\end{array}$ & & $\begin{array}{l}-0.003 \\
(0.007)\end{array}$ & $\begin{array}{l}-0.003 \\
(0.006)\end{array}$ & $\begin{array}{l}-0.003 \\
(0.007)\end{array}$ & $\begin{array}{c}0.005 \\
(0.006)\end{array}$ \\
\hline India X 4 yr. delay & & $\begin{array}{c}0.027 \\
(0.025)\end{array}$ & & $\begin{array}{l}-0.011 \\
(0.022)\end{array}$ & & & & \\
\hline India X 5 yr. delay & & $\begin{array}{l}0.051^{*} \\
(0.023)\end{array}$ & & $\begin{array}{l}-0.022 \\
(0.021)\end{array}$ & & & & \\
\hline India X 6 yr. delay & & $\begin{array}{c}0.107 * * \\
(0.033)\end{array}$ & & $\begin{array}{l}-0.012 \\
(0.023)\end{array}$ & & & & \\
\hline India $X 7$ yr. delay & & $\begin{array}{c}0.086^{* *} \\
(0.031)\end{array}$ & & $\begin{array}{c}0.040 \\
(0.048)\end{array}$ & & & & \\
\hline India $X 8$ yr. delay & & $\begin{array}{l}0.139^{* *} \\
(0.048)\end{array}$ & & $\begin{array}{l}-0.011 \\
(0.033)\end{array}$ & & & & \\
\hline China X 2 yr. delay & & $\begin{array}{c}0.071^{* *} \\
(0.025)\end{array}$ & & $\begin{array}{l}-0.007 \\
(0.019)\end{array}$ & & & & \\
\hline China X 3 yr. delay & & $\begin{array}{c}0.088^{* * * *} \\
(0.025)\end{array}$ & & $\begin{array}{c}0.014 \\
(0.019)\end{array}$ & & & & \\
\hline China X 4 yr. delay & & $\begin{array}{c}0.077 * * * \\
(0.017)\end{array}$ & & $\begin{array}{c}0.008 \\
(0.012)\end{array}$ & & & & \\
\hline China X 5 yr. delay & & $\begin{array}{c}0.118^{* * * *} \\
(0.020)\end{array}$ & & $\begin{array}{c}0.013 \\
(0.015)\end{array}$ & & & & \\
\hline India & $\begin{array}{c}-0.142^{* * *} \\
(0.026)\end{array}$ & $\begin{array}{c}-0.167 * * * \\
(0.031)\end{array}$ & $\begin{array}{c}0.019 \\
(0.0225)\end{array}$ & $\begin{array}{c}0.030 \\
(0.027)\end{array}$ & $\begin{array}{l}-0.105^{*} \\
(0.048)\end{array}$ & $\begin{array}{l}-0.075 \\
(0.044)\end{array}$ & $\begin{array}{l}-0.106^{*} \\
(0.048)\end{array}$ & $\begin{array}{l}-0.091 * \\
(0.043)\end{array}$ \\
\hline China & $\begin{array}{c}-0.194 * * * \\
(0.027)\end{array}$ & $\begin{array}{c}-0.202 * * * \\
(0.027)\end{array}$ & $\begin{array}{l}-0.039 \\
(0.023)\end{array}$ & $\begin{array}{l}-0.036 \\
(0.024)\end{array}$ & $\begin{array}{c}-0.174 * * * \\
(0.049)\end{array}$ & $\begin{array}{c}-0.168 * * * \\
(0.045)\end{array}$ & $\begin{array}{c}-0.186^{* * *} \\
(0.048)\end{array}$ & $\begin{array}{c}-0.173 * * * \\
(0.044)\end{array}$ \\
\hline $\begin{array}{l}\text { For support during } \\
\text { grad school }\end{array}$ & $\begin{array}{c}0.339^{* * *} \\
(0.019)\end{array}$ & $\begin{array}{c}0.337^{* * * *} \\
(0.019)\end{array}$ & $\begin{array}{l}(0.009) \\
(0.014)\end{array}$ & $\begin{array}{l}(0.009) \\
(0.014)\end{array}$ & $\begin{array}{c}0.016 \\
(0.054)\end{array}$ & $\begin{array}{l}0.0132 \\
(0.051)\end{array}$ & $\begin{array}{c}0.046 \\
(0.047)\end{array}$ & $\begin{array}{c}0.019 \\
(0.048)\end{array}$ \\
\hline R-squared & 0.189 & 0.189 & 0.052 & 0.052 & 0.136 & 0.189 & 0.178 & 0.241 \\
\hline \# observations & 22,470 & 22,470 & 22,470 & 22,470 & 11,168 & 13.202 & 11,168 & 13.202 \\
\hline
\end{tabular}


Table 5: Visa Delays, Visa Status and Salaries

\begin{tabular}{llll} 
& $\begin{array}{l}\text { Temporary } \\
\text { Resident }\end{array}$ & \multicolumn{2}{c}{ Salary } \\
\hline & $(1)$ & $(2)$ & $(3)$ \\
\hline India X long delay & $0.0751^{*}$ & & -0.0132 \\
& $(0.0344)$ & & $(0.0327)$ \\
China X visa delay & $0.0141^{* *}$ & & 0.0082 \\
& $(0.0046)$ & & $(0.0072)$ \\
Temporary resident & & $-0.0492^{* * *}$ & \\
& & $(0.0143)$ & \\
India & $0.1382^{* * *}$ & $0.1083^{*}$ & $0.0994^{*}$ \\
& $(0.0342)$ & $(0.0461)$ & $(0.0467)$ \\
China & $0.1505^{* * *}$ & $0.1216^{* *}$ & $0.0923^{*}$ \\
& $(0.0315)$ & $(0.0396)$ & $(0.0463)$ \\
\hline R-squared & 0.3370 & 0.2530 & 0.2522 \\
$\mathrm{~N}$ & 13202 & 13193 & 13193
\end{tabular}

$* \mathrm{p}<0.05, * * \mathrm{p}<0.01, * * * \mathrm{p}<0.001$. Robust standard errors, clustered by respondent, in parentheses. All regressions include fixed effects for survey year, year of $\mathrm{PhD}$, and 2-digit field of study. See note on Table 2 for additional controls. In column 1, the dependent variable is a dummy indicating that the respondent is a temporary resident. In columns $2-3$, the dependent variable is $\ln$ (salary). 


\section{Appendix}

\section{Stay rates in the long run}

We assess the impact of per-country limits on permanent residency visas on more permanent location in a several different models. In the first model, we model stay rates of those who are more than 3 years post-PhD and assume that new $\mathrm{PhDs}$ make their joint plan for postdoc/OPT and more permanent employment location simultaneously around the time of $\mathrm{PhD}$ receipt. This analysis automatically excludes everyone who obtained PhDs after Jan. 2012, since 3 years had not yet elapsed by the time of the most recently available (Feb. 2015) survey. Similarly, observations in the 2013 survey are truncated at Sept. 2010, and observations in the 2010 survey are truncated at Jan. 2007. We also exclude everyone who stated that they were working on a postdoc when they responded to the SDR, even if they were more than 3 year post-PhD.

Results are shown in Column 1 (compact model) of Appendix Table 4 (re-estimates of the models of Table 2 Column 7.) Here, we find that the impact of each year of visa delay remains substantial and significant for Chinese doctoral recipients $(-2.14$ ppt. per year, $t=-4.39)$. However, for Indians, the long run impact of long $\left(5^{1 / 2}+\right.$ years $)$ visa delays is $-5.74 \mathrm{ppt}$. but insignificant at typical levels $(\mathrm{t}=-1.44 \mathrm{p}=.149)$. Note that since this long-run location model excludes the very latest PhDs, there are no Indians with 7 or 8 year delays at $\mathrm{PhD}$ (occurring in years 2012 and 2013) - the group with the largest reduction in stay rates - and only 186 observations with a 6 year delay. As a result, the coefficient and degree of significance on the Indian long-delay variable are smaller than in the full model of Indian stay rates in Table 2 Column 7.

In our second long run model, we consider the possibility that PhDs postpone their employmentlocation decisions until they complete their postdocs or OPT, or have worked for a few years. In this case, long run choices would still be modeled as the choices of those observed 3 or more years post-PhD excluding those currently in postdocs, but they would react to visa delays at 3 years post-PhD. This model 
is shown in Appendix Table 4 Column 2. This model fits the data less well. Finally, because limiting to 3 years post-PhD cut out the Indian respondents with the longest delays, we also estimate a regression with no limit on years-from-PhD but simply excluding those currently in a postdoc (Appendix Table 4

Column 3). The impact of one more year of delay for Chinese virtually unchanged, but now the effect of long Indian delays - which now include delays as long as 8 years, returns to their previous large coefficient size and significance (-8.39 ppt., $\mathrm{t}=-2.66)$.

Finally, we note that Khosla (2018) tried to estimate the long run impact (6-11 years post-PhD) of the visa delay on scientists using years-since-PhD. Since year of $\mathrm{PhD}$, survey year and years-since-PhD are perfectly collinear - meaning that you cannot disentangle the three time effects -- she had to make arbitrary assumptions to do this. Specifically, she grouped years from $\mathrm{PhD}$ into 4 ranges. However, this is an arbitrary choice and it make no more sense to group years from $\mathrm{PhD}$ than to group $\mathrm{PhD}$ year. In other words, it is impossible to differentiate between cohort ( $\mathrm{PhD}$ year) effects and career-stage effects, given the existence of survey-year effects, without making arbitrary assumptions. Also, it is not surprising that she found no effect since she only had 2010 and 2013 SDRs (with only PhDs granted earlier), and given the tiny sample of people 6 or more years from $\mathrm{PhD}$ (who had faced a visa constraint at $\mathrm{PhD}$ by the Feb. 2013 survey and had been subject to a visa cap by graduating post-2005).

\section{Intended $v$. actual stay rates}

We cannot apply similar analysis to model the impact of the imposition of EB-2 application delays on immediate post-PhD locations, because our earliest SDR survey that followed doctorates who moved abroad (2010) was more than 4 years since the visa delay became binding. The best we can do is what others have done, i.e. use students' intentions to stay in the US when surveyed at the time of PhD receipt to proxy short run stay rates. 
In Appendix Table 4 Columns 4 and 5, the dependent variable is "Intend to stay in the US". ${ }^{1}$ In Column 4, the coefficient on each year of delay for the Chinese is significant but smaller than in our stay rate models $(-0.93)$, while for India the effect of long delays (at $\mathrm{PhD})$ is not significant $(\mathrm{t}=-0.26)$. In Column 5, we repeat the analysis but excluding those intending postdocs from the analysis. In this case, even the China visa coefficient is not significant $(\mathrm{t}=-1.25)$.

We note that Khosla (2018) found a -1.4 ppt. significant average effect of EB-2 visa delays on intentions (for PhDs 2001+, with a much larger sample including the entire SED STEM population but without 2015.) Estimating a single average visa effect in our dataset, limiting ourselves to data from the earlier surveys (2010 and 2013 surveys) and including post-docs, as in her analysis, we find an average effect (-1.13 ppt. $\mathrm{t}=-2.32)$ quite similar to hers. However, when we add in the much larger 2015 sample with longer Indian delays, we get a smaller and insignificant value $(-0.57 \mathrm{ppt} ., \mathrm{t}=-1.54)$.

To summarize, when we include the survey wave of 2015 (and therefore longer visa delays) but exclude those who intend postdocs, the visa delays seem to have little impact on Chinese STEM PhDs' intentions to remain in the US (for those who don't enter a postdoc after $\mathrm{PhD}$ ), and no effect on Indians' location intentions at $\mathrm{PhD}$. This may be for a variety of reasons: perhaps the $\mathrm{PhDs}$ are overly optimistic about getting an $\mathrm{H}-1 \mathrm{~B}$ or about the kind of job they could get in the US, or do not realize the disadvantages of remaining temporary residents.

However, intentions to remain in the US - even excluding those intending to enter postdocs, may not match actual location, for instance because the person is unable to get a temporary work visa. The correlation coefficient between SED intentions to remain in the US and actually being observed in the US is 0.59 in our sample (excluding students from India and China who may have been affected by the EB-2

\footnotetext{
${ }^{1}$ We include only a single observation for those observed in more than one SDR, since this is an SEDderived variable only measured once (at $\mathrm{PhD}$ completion).
} 
visas.) $)^{2}$ Thus intentions and stay rates - especially short-run stay rates -- are highly correlated, yet intentions are an imperfect predictor of whether or not these PhDs actually do remain.

Do EB-2 visa delays affect US stay rates, even controlling for intentions to remain? Appendix Table 4 Column 6 displays a regression in which the dependent variable is a dummy for remaining in the US (excluding those in postdocs, as in Appendix Table 4 Column 3) but adding a control for whether or not the person intended to remain at $\mathrm{PhD}$. Intending to stay in the US is associated with a (highly significant) 48.1 ppt. increase in actually being observed in the US ceteris paribus. Yet, conditioning on location intentions, the visa delay length continues to have a highly significant effect on the probability of actually remaining in the US for Chinese PhDs at all delay lengths averaging 1.52 ppt. per year $(\mathrm{t}=-3.51$ Column 6). For India, results are similar to what they were without intentions as a control: long delays deter stay rates by 8.2 ppt. $(\mathrm{t}=-2.77)$.

We conclude that for Chinese STEM PhDs, visa delays at PhD impact actual locations in the long run. However, they do not seem to have a major impact on Chinese intentions to remain in the US (at $\mathrm{PhD})$ for those who don't enter a postdoc after $\mathrm{PhD}$. Shorter visa delays $\left(<5 \frac{1}{2}\right.$ years $)$ at $\mathrm{PhD}$ have no impact on Indian locations in the long run, but it is difficult to ascertain the long run impact of very long delays on Indians given our limited years of data. No delays - short or long - affect Indians' location intentions at $\mathrm{PhD}$, which only partially mirror later actual locations.

\footnotetext{
${ }^{2}$ If we limit ourselves to those within 3 years of the survey, this correlation coefficient rises to 0.68 .
} 
Appendix Table 1a Descriptive statistics on Temporary Residents at PhD (PhD years 2001 - 2013)

Employed in SDR 2010, 13, 15

\begin{tabular}{|c|c|c|c|c|}
\hline & Full Sample & From India & From China & From RoW \\
\hline $\mathrm{N}$ & 22,470 & 2,457 & 5,155 & 14,858 \\
\hline Stay rate & 0.682 & 0.847 & 0.875 & 0.541 \\
\hline Return rate & 0.215 & 0.088 & 0.081 & 0.316 \\
\hline \multirow[t]{2}{*}{ In third country } & 0.103 & 0.065 & 0.044 & 0.143 \\
\hline & \multicolumn{4}{|c|}{ Personal Characteristics } \\
\hline Male single, no children & 0.132 & 0.129 & 0.071 & 0.165 \\
\hline Female & 0.286 & 0.210 & 0.301 & 0.297 \\
\hline Male Married at $\mathrm{PhD}$ & 0.400 & 0.311 & 0.512 & 0.364 \\
\hline Female Married at $\mathrm{PhD}$ & 0.135 & 0.113 & 0.199 & 0.108 \\
\hline Male child at $\mathrm{PhD}$ & 0.213 & 0.086 & 0.235 & 0.232 \\
\hline Male child at PhD - missing & 0.050 & 0.053 & 0.043 & 0.052 \\
\hline Male single at $\mathrm{PhD}$ & 0.267 & 0.420 & 0.156 & 0.286 \\
\hline Female Child at $\mathrm{PhD}$ & 0.058 & 0.027 & 0.080 & 0.055 \\
\hline Female child at $\mathrm{PhD}$ - missing & 0.020 & 0.008 & 0.019 & 0.023 \\
\hline black & 0.030 & 0.002 & 0.000 & 0.052 \\
\hline asian & 0.680 & 0.991 & 0.997 & 0.440 \\
\hline hispanic & 0.063 & 0.002 & 0.001 & 0.110 \\
\hline Age at $\mathrm{PhD}$ & 31.423 & 29.093 & 30.834 & 32.300 \\
\hline Foreign support & 0.041 & 0.001 & 0.001 & 0.071 \\
\hline medical & 0.040 & 0.044 & 0.050 & 0.034 \\
\hline In a postdoc & 0.121 & 0.135 & 0.112 & 0.122 \\
\hline Father college grad & 0.545 & 0.816 & 0.414 & 0.546 \\
\hline Sample year 2010 & 0.270 & 0.241 & 0.271 & 0.277 \\
\hline Sample year 2013 & 0.336 & 0.338 & 0.325 & 0.341 \\
\hline Sample year 2015 & 0.394 & 0.421 & 0.404 & 0.382 \\
\hline PhD Rank top $10 \%$ & 0.088 & 0.059 & 0.061 & 0.109 \\
\hline Average PhD Rank & 101.818 & 110.888 & 111.968 & 94.326 \\
\hline \multirow[t]{2}{*}{ PhD inst unranked } & 0.122 & 0.154 & 0.114 & 0.118 \\
\hline & \multicolumn{4}{|c|}{ Country Characteristics } \\
\hline Top 20 in publication rank & 0.731 & 1 & 1 & 0.526 \\
\hline Pub rank 21-50 & 0.158 & 0 & 0 & 0.279 \\
\hline Pub rank 51-100 & 0.094 & 0 & 0 & 0.165 \\
\hline Pub rank 101-200 & 0.017 & 0 & 0 & 0.029 \\
\hline English official language & 0.228 & 1 & 0 & 0.157 \\
\hline Distance from US & 10.015 & 11.762 & 10.994 & 9.078 \\
\hline Polity & 3.040 & 9 & -7 & 6.801 \\
\hline ln Citations per article & 2.139 & 2.045 & 1.471 & 2.509 \\
\hline GDP per capita rel. to US & 0.315 & 0.072 & 0.133 & 0.470 \\
\hline R\&D/GDP (\%) & 1.319 & 0.802 & 1.335 & 1.444 \\
\hline
\end{tabular}




\section{Appendix Table 1b Descriptive statistics on Temporary Residents at PhD (PhD years 2001 - 2013) Employed in in the US (SDR 2010, 13, 15)}

\begin{tabular}{lrrrr} 
& \multicolumn{4}{c}{ Including Postdocs } \\
\cline { 2 - 5 } $\mathrm{N}$ & Full Sample & From India & From China & From RoW \\
& 13,202 & 1,961 & 4,347 & 6,894 \\
\hline Temporary resident & $33.362 \%$ & $46.826 \%$ & $31.257 \%$ & $29.948 \%$ \\
Employed in Academia & $41.602 \%$ & $32.068 \%$ & $33.637 \%$ & $51.958 \%$ \\
Employed by small firm & $4.963 \%$ & $4.438 \%$ & $4.818 \%$ & $5.287 \%$ \\
Employed in not for profit & $51.905 \%$ & $40.463 \%$ & $43.760 \%$ & $63.147 \%$ \\
Self employed & $4.133 \%$ & $2.429 \%$ & $6.194 \%$ & $3.058 \%$ \\
Self employed, incorporated & $3.422 \%$ & $2.112 \%$ & $5.371 \%$ & $2.291 \%$ \\
Employed in Start-up & $2.154 \%$ & $2.157 \%$ & $1.981 \%$ & $2.298 \%$ \\
& & & & \\
Salary (2011\$) & $100,085.70$ & $99,977.87$ & $112,053.90$ & $90,080.04$ \\
Years w current employer & 3.827 & 3.422 & 3.982 & 3.852
\end{tabular}

Excluding post docs

\begin{tabular}{lrrrr} 
& \multicolumn{4}{c}{ Excluding post docs } \\
\cline { 2 - 5 } $\mathrm{N}$ & Full Sample & From India & From China & From RoW \\
\hline Temporary resident & 11,168 & 1,625 & 3,748 & 5,795 \\
Employed in Academia & $27.525 \%$ & $41.065 \%$ & $26.531 \%$ & $23.065 \%$ \\
Employed by small firm & $35.783 \%$ & $24.763 \%$ & $27.930 \%$ & $47.049 \%$ \\
Employed in not for profit & $5.379 \%$ & $4.795 \%$ & $5.178 \%$ & $5.787 \%$ \\
Self employed & $44.692 \%$ & $31.396 \%$ & $36.887 \%$ & $56.813 \%$ \\
Self employed, incorporated & $4.795 \%$ & $2.827 \%$ & $6.982 \%$ & $3.644 \%$ \\
Employed in Start-up & $3.986 \%$ & $2.458 \%$ & $6.095 \%$ & $2.729 \%$ \\
& $2.489 \%$ & $2.433 \%$ & $2.248 \%$ & $2.723 \%$ \\
Salary (2011\$) & & & & \\
Years w current employer & $108,406.30$ & $108,344.30$ & $120,578.00$ & $97,701.71$ \\
& 4.025 & 3.593 & 4.120 & 4.112
\end{tabular}


Appendix Table 2: Distributions Across Fields

\begin{tabular}{|c|c|c|c|c|c|c|}
\hline & \multirow{2}{*}{$\begin{array}{c}\text { Total Employed } \\
\text { in US }\end{array}$} & \multicolumn{5}{|c|}{ STEM PhDs by field } \\
\hline & & Total PhDs granted & From US* & From China** & From India** & From RoW** \\
\hline Computer sciences & $4.18 \%$ & $4.15 \%$ & $2.85 \%$ & $7.22 \%$ & $8.50 \%$ & $4.83 \%$ \\
\hline Math/Stats & $4.32 \%$ & $4.57 \%$ & $3.40 \%$ & $7.55 \%$ & $3.41 \%$ & $6.17 \%$ \\
\hline Agr/Food Sciences & $1.78 \%$ & $2.04 \%$ & $1.58 \%$ & $1.73 \%$ & $2.09 \%$ & $3.27 \%$ \\
\hline Biological Sciences & $22.79 \%$ & $21.77 \%$ & $25.10 \%$ & $19.29 \%$ & $18.74 \%$ & $15.70 \%$ \\
\hline Eviron. Life Sciences & $1.31 \%$ & $1.35 \%$ & $1.51 \%$ & $0.74 \%$ & $0.38 \%$ & $1.49 \%$ \\
\hline Chemistry & $7.14 \%$ & $6.95 \%$ & $6.63 \%$ & $10.01 \%$ & $6.40 \%$ & $6.34 \%$ \\
\hline Earth/Ocean/Atmosphere & $1.98 \%$ & $2.08 \%$ & $2.14 \%$ & $2.16 \%$ & $1.26 \%$ & $2.08 \%$ \\
\hline Physics/Astronomy & $4.88 \%$ & $5.13 \%$ & $4.38 \%$ & $5.84 \%$ & $4.51 \%$ & $6.71 \%$ \\
\hline Other Phys Sci & $0.36 \%$ & $0.35 \%$ & $0.43 \%$ & $0.19 \%$ & $0.10 \%$ & $0.31 \%$ \\
\hline Economics & $2.83 \%$ & $3.61 \%$ & $2.12 \%$ & $2.88 \%$ & $3.17 \%$ & $7.61 \%$ \\
\hline Political Science & $2.78 \%$ & $2.92 \%$ & $3.55 \%$ & $0.57 \%$ & $1.00 \%$ & $2.95 \%$ \\
\hline Psychology & $12.34 \%$ & $11.34 \%$ & $17.43 \%$ & $1.04 \%$ & $0.97 \%$ & $4.07 \%$ \\
\hline Sociology, anthropology & $3.73 \%$ & $3.72 \%$ & $5.08 \%$ & $0.56 \%$ & $0.36 \%$ & $2.76 \%$ \\
\hline Other Social Sciences & $2.59 \%$ & $2.89 \%$ & $3.35 \%$ & $0.82 \%$ & $0.69 \%$ & $3.27 \%$ \\
\hline Aerospace engineering & $0.77 \%$ & $0.75 \%$ & $0.58 \%$ & $0.54 \%$ & $1.66 \%$ & $1.04 \%$ \\
\hline Chemical engineering & $2.28 \%$ & $2.29 \%$ & $1.75 \%$ & $3.37 \%$ & $6.08 \%$ & $2.21 \%$ \\
\hline Civil/Architectural eng & $1.68 \%$ & $1.92 \%$ & $0.97 \%$ & $3.01 \%$ & $1.85 \%$ & $3.67 \%$ \\
\hline Electrical/Computer eng & $6.33 \%$ & $6.37 \%$ & $2.86 \%$ & $14.45 \%$ & $14.02 \%$ & $9.18 \%$ \\
\hline Industrial engineering & $0.73 \%$ & $0.80 \%$ & $0.35 \%$ & $1.24 \%$ & $1.72 \%$ & $1.48 \%$ \\
\hline Mechanical engineering & $3.15 \%$ & $3.10 \%$ & $1.99 \%$ & $5.55 \%$ & $6.89 \%$ & $3.72 \%$ \\
\hline Other engineering & $5.85 \%$ & $5.91 \%$ & $4.59 \%$ & $8.79 \%$ & $11.07 \%$ & $6.53 \%$ \\
\hline Health, Other & $6.22 \%$ & $5.99 \%$ & $7.37 \%$ & $2.46 \%$ & $5.12 \%$ & $4.61 \%$ \\
\hline Total & $100 \%$ & $100 \%$ & $100 \%$ & $100 \%$ & $100 \%$ & $100 \%$ \\
\hline
\end{tabular}

* US-born and naturalized citizens. ** Population includes temporary and permanent residents at PhD from these countries. RoW Rest of World. 
Appendix Table 3: Coefficients on Control Variables from Table 2 Column 7

Female

Male married at $\mathrm{PhD}$

Female married at $\mathrm{PhD}$

Male w. child at $\mathrm{PhD}$

Female w. child at $\mathrm{PhD}$

Female - missing data on child at $\mathrm{PhD}$

Male - missing data on child at $\mathrm{PhD}$

African American

Asian

Hispanic

Age at $\mathrm{PhD}$

Foreign support during $\mathrm{PhD}$

$\mathrm{PhD}$ from medical school

In a postdoc

Father had BA

Survey year 2013

Survey year 2015

$\mathrm{PhD}$ inst rank 11-25

$\mathrm{PhD}$ inst rank 26-50

PhD inst rank 51-100

PhD inst rank 101-200

PhD inst rank 201-300

PhD inst rank 301-400

$\mathrm{PhD}$ inst rank 401-500

\begin{tabular}{|c|c|}
\hline $\begin{array}{l}0.0232 \\
(0.014)\end{array}$ & $\mathrm{PhD}$ inst unranked \\
\hline $\begin{array}{c}0.0722 * * * \\
(0.012)\end{array}$ & Math/Stats \\
\hline $\begin{array}{c}0.0514 * * * \\
(0.0149)\end{array}$ & Agr/Food Sciences \\
\hline $\begin{array}{c}-0.0371^{* *} \\
(0.013)\end{array}$ & Biological Sciences \\
\hline $\begin{array}{l}-0.0349 \\
(0.022)\end{array}$ & Eviron. Life Sciences \\
\hline $\begin{array}{l}-0.0181 \\
(0.018)\end{array}$ & Chemistry \\
\hline $\begin{array}{l}-0.0531 \\
(0.028)\end{array}$ & Earth/Ocean/Atmosphere \\
\hline $\begin{array}{l}-0.0056 \\
(0.027)\end{array}$ & Physics/Astronomy \\
\hline $\begin{array}{l}-0.0500 * * \\
(0.019)\end{array}$ & Other Phys Sci \\
\hline $\begin{array}{c}-0.0531 * * \\
(0.019)\end{array}$ & Economics \\
\hline $\begin{array}{c}-0.0077 * * * \\
(0.001)\end{array}$ & Political Science \\
\hline $\begin{array}{l}-0.3292 * * * \\
(0.018)\end{array}$ & Psychology \\
\hline $\begin{array}{l}0.0313 \\
(0.021)\end{array}$ & Sociology, anthropology \\
\hline $\begin{array}{c}0.1059 * * * \\
(0.0119)\end{array}$ & Other Social Sciences \\
\hline $\begin{array}{l}0.0058 \\
(0.009)\end{array}$ & Aerospace engineering \\
\hline $\begin{array}{l}-0.0149 * * \\
(0.005)\end{array}$ & Chemical engineering \\
\hline $\begin{array}{l}-0.0018 \\
(0.009)\end{array}$ & Civil/Architectural engineering \\
\hline $\begin{array}{l}-0.0311 \\
(0.020)\end{array}$ & Electrical/Computer engineering \\
\hline $\begin{array}{l}-0.0135 \\
(0.019)\end{array}$ & Industrial engineering \\
\hline $\begin{array}{l}-0.007 \\
(0.018)\end{array}$ & Mechanical engineering \\
\hline $\begin{array}{l}0.0013 \\
(0.018)\end{array}$ & Other engineering \\
\hline $\begin{array}{l}0.0091 \\
(0.021)\end{array}$ & Health \\
\hline $\begin{array}{l}-0.0162 \\
(0.025)\end{array}$ & Other \\
\hline $\begin{array}{l}-0.001 \\
(0.025)\end{array}$ & Phd Year 2002 \\
\hline
\end{tabular}

PhD Year 2003

PhD Year 2004

PhD Year 2005

PhD Year 2006

PhD Year 2007

PhD Year 2008

PhD Year 2009

PhD Year 2010

PhD Year 2011

PhD Year 2012

PhD Year 2013

Country ranked $21-50$ in publications

Country ranked 51-100 in publications

Country ranked 101-250 in publications

English is official language of $\mathrm{HC}$

Distance to $\mathrm{HC}$

Polity

Missing polity score

Cites per article in $\mathrm{HC}$ bef. $\mathrm{PhD}$ year

GPD per cap. HC /US (PPP) bef PhD year

R\&D \%GDP in HC bef PhD year

R\&D\% GDP missing
$-0.0748^{* *}$

$(0.025)$

$-0.0480^{*}$

$(0.023)$

$-0.0217$

$(0.023)$

$-0.0501 *$

(0.023)

$-0.0585^{* *}$

$(0.022)$

$-0.0388$

$-0.0388$

$(0.023)$

$-0.0463$

$(0.024)$

(0.026)

$-0.1190 * * *$

(0.027)

$-0.1264 * * *$

$(0.0309)$

$-0.1244 * *$
$(0.033)$

$-0.0268$

$(0.019)$

$0.0919 * * *$

$(0.025)$

$0.1260 * * *$

(0.038)

$0.1206^{* * *}$

$(0.020)$

$-0.0083^{* *}$

(0.003)

0.0016

$(0.002)$

-0.2081 *

(0.082)

$-0.1592 * * *$

(0.019)

$-0.0173$

(0.030)

0.0194

$(0.0101)$

0.041

(0.027) 


\section{Appendix Table 4: Timing of the Effect and Intentions}

(1)

(4)

(5)

(6)

\begin{tabular}{|c|c|c|c|c|c|c|}
\hline & $\begin{array}{r}\text { Long run }> \\
\mathrm{pc}\end{array}$ & excluding & $\begin{array}{l}\text { All yrs, } \\
\text { excluding } \\
\text { postdocs }\end{array}$ & $\begin{array}{c}\text { Intend to } \\
\text { stay }\end{array}$ & $\begin{array}{c}\text { Intend to } \\
\text { stay but not } \\
\text { for a } \\
\text { postdoc }\end{array}$ & $\begin{array}{l}\text { Stay in US, } \\
\text { with } \\
\text { intentions } \\
\text { (excl. } \\
\text { postdocs) }\end{array}$ \\
\hline India $X$ long delay & $\begin{array}{c}-0.057 \\
(0.040)\end{array}$ & & $\begin{array}{c}-0.084 * * \\
(0.032)\end{array}$ & $\begin{array}{l}-0.007 \\
(0.026)\end{array}$ & $\begin{array}{l}-0.010 \\
(0.034)\end{array}$ & $\begin{array}{c}-0.082 * * \\
(0.030)\end{array}$ \\
\hline China $\mathrm{X}$ delay & $\begin{array}{c}-0.021 * * * \\
(0.005)\end{array}$ & & $\begin{array}{c}-0.0218 * * * \\
(0.004)\end{array}$ & $\begin{array}{l}-0.009 * \\
(0.004)\end{array}$ & $\begin{array}{l}-0.007 \\
(0.006)\end{array}$ & $\begin{array}{c}-0.015 * * * \\
(0.004)\end{array}$ \\
\hline India $X$ long delay at 3 yrs & & $\begin{array}{c}0.041 \\
(0.025)\end{array}$ & & & & \\
\hline China $X$ delay at 3 yrs & & $\begin{array}{c}0.0009 \\
(0.007)\end{array}$ & & & & \\
\hline$=1$ if individual planned to stay in US after grad & & & & & & $\begin{array}{c}0.481^{* * *} \\
(0.011)\end{array}$ \\
\hline India & $\begin{array}{c}0.134 * * * \\
(0.036)\end{array}$ & $\begin{array}{c}0.127 * * * \\
(0.036)\end{array}$ & $\begin{array}{c}0.146^{* * *} * \\
(0.033)\end{array}$ & $\begin{array}{c}0.058 \\
(0.030)\end{array}$ & $\begin{array}{c}0.095^{*} \\
(0.038)\end{array}$ & $\begin{array}{c}0.111 * * * \\
(0.029)\end{array}$ \\
\hline China & $\begin{array}{c}0.260 * * * \\
(0.037)\end{array}$ & $\begin{array}{c}0.220 * * * \\
(0.035)\end{array}$ & $\begin{array}{c}0.255^{* * *} * \\
(0.034)\end{array}$ & $\begin{array}{c}0.052 \\
(0.031) \\
\end{array}$ & $\begin{array}{l}0.094^{*} \\
(0.040) \\
\end{array}$ & $\begin{array}{c}0.207 * * * \\
(0.031) \\
\end{array}$ \\
\hline $\begin{array}{l}\text { R-squared } \\
\mathrm{N}\end{array}$ & $\begin{array}{c}0.220 \\
17,128\end{array}$ & $\begin{array}{c}0.219 \\
17,128\end{array}$ & $\begin{array}{c}0.215 \\
19,716\end{array}$ & $\begin{array}{c}0.155 \\
15,875\end{array}$ & $\begin{array}{c}0.193 \\
10,516\end{array}$ & $\begin{array}{c}0.395 \\
19,283\end{array}$ \\
\hline
\end{tabular}

$* \mathrm{p}<0.05, * * \mathrm{p}<0.01, * * * \mathrm{p}<0.001$. Robust standard errors, clustered by respondent, in parentheses. All regressions include fixed effects for survey year, year of PhD, and 2-digit field of study. See note on Table 2 for additional controls. The dependent variable in Columns 1-3 and 6 is a dummy for staying in the US. Columns 1 and 2 exclude respondents within 3 years of $\mathrm{PhD}$ receipt. Columns 3, 5 and 6 exclude people currently employed in postdocs. The dependent variable in Column 4 and 5 is a dummy for stating intentions to stay in the US at time of $\mathrm{PhD}$ receipt, and include only one observation per person. 
Appendix Table 5: Miscellaneous Regressions, dependent variable: Staying in the US

\begin{tabular}{|c|c|c|c|c|c|c|c|c|c|c|}
\hline & $\begin{array}{c}(1) \\
\text { with years } \\
\text { from } \mathrm{PhD} \\
\text { instead }\end{array}$ & $\begin{array}{c}\text { (2) } \\
\text { clustering by } \\
\text { country }\end{array}$ & $\begin{array}{c}\text { (3) } \\
\text { with } \\
\text { country } \\
\text { FE }\end{array}$ & $\begin{array}{c}\text { (4) } \\
\text { dif China, } \\
\text { India survey } \\
\text { year effects }\end{array}$ & $\begin{array}{l}\text { (5) } \\
\text { excl. } \\
\text { recession }\end{array}$ & $\begin{array}{c}(6) \\
\text { Including } \\
\text { caps for } \\
2001\end{array}$ & $\begin{array}{c}(7) \\
\text { High/other } \\
\text { excess } \\
\text { demand }\end{array}$ & $\begin{array}{c}\text { (8) } \\
\text { Inst rank } \\
\text { interactions }\end{array}$ & $\begin{array}{c}(9) \\
\text { Publication } \\
\text { country-field } \\
\text { rank X visa }\end{array}$ & $\begin{array}{c}\quad(10) \\
\text { exc. Science } \\
\text { variables }\end{array}$ \\
\hline India $\mathrm{X}$ long delay & $\begin{array}{c}-0.090 * * * \\
(0.026)\end{array}$ & $\begin{array}{c}-0.089 * * * \\
(0.011)\end{array}$ & $\begin{array}{c}-0.081 * * \\
(0.027)\end{array}$ & $\begin{array}{c}-0.084 * * \\
(0.027)\end{array}$ & $\begin{array}{c}-0.104 * * \\
(0.038)\end{array}$ & $\begin{array}{c}-0.088^{* * *} \\
(0.027)\end{array}$ & $\begin{array}{c}-0.098 * * \\
(0.049)\end{array}$ & $\begin{array}{c}-0.084 * * \\
(0.027)\end{array}$ & $\begin{array}{l}-0.136^{*} \\
(0.057)\end{array}$ & $\begin{array}{c}-0.080 * * \\
(0.027)\end{array}$ \\
\hline China $\mathrm{X}$ delay & $\begin{array}{c}-0.022 * * * \\
(0.004)\end{array}$ & $\begin{array}{c}-0.024 * * * \\
(0.004)\end{array}$ & $\begin{array}{c}-0.023^{* * *} \\
(0.004)\end{array}$ & $\begin{array}{c}-0.024^{* * *} \\
(0.004)\end{array}$ & $\begin{array}{c}-0.022 * * * \\
(0.005)\end{array}$ & $\begin{array}{c}-0.024 * * * \\
(0.004)\end{array}$ & $\begin{array}{c}-0.031 * * * \\
(0.007)\end{array}$ & $\begin{array}{c}-0.020^{* * *} \\
(0.006)\end{array}$ & $\begin{array}{c}-0.019 * * * \\
(0.005)\end{array}$ & $\begin{array}{c}-0.022^{* * *} \\
(0.004)\end{array}$ \\
\hline $\begin{array}{l}\text { India X long delay X } \\
\text { excess demand }\end{array}$ & & & & & & & $\begin{array}{c}0.013 \\
(0.057)\end{array}$ & & & \\
\hline $\begin{array}{l}\text { China X delay X excess } \\
\text { demand }\end{array}$ & & & & & & & $\begin{array}{c}0.010 \\
(0.007)\end{array}$ & & & \\
\hline $\begin{array}{l}\text { India X capped X } \\
\text { ranked } 51-200\end{array}$ & & & & & & & & $\begin{array}{c}0.015 \\
(0.044)\end{array}$ & & \\
\hline $\begin{array}{l}\text { India X capped X } \\
\text { ranked } 201+\end{array}$ & & & & & & & & $\begin{array}{l}-0.062 \\
(0.043)\end{array}$ & & \\
\hline $\begin{array}{l}\text { China X capped X } \\
\text { ranked } 51-200\end{array}$ & & & & & & & & $\begin{array}{l}-0.010 \\
(0.028)\end{array}$ & & \\
\hline $\begin{array}{l}\text { China X capped X } \\
\text { ranked } 201+\end{array}$ & & & & & & & & $\begin{array}{l}-(0.042 \\
(0.030)\end{array}$ & & \\
\hline $\begin{array}{l}\text { India X capped X } \\
\text { country-field rank }\end{array}$ & & & & & & & & & $\begin{array}{c}0.005 \\
(0.005)\end{array}$ & \\
\hline $\begin{array}{l}\text { China X capped X } \\
\text { country-field rank }\end{array}$ & & & & & & & & & $\begin{array}{l}(0.001) \\
(0.000)\end{array}$ & \\
\hline $\begin{array}{l}\text { R-squared } \\
\mathrm{N}\end{array}$ & $\begin{array}{l}0.2064 \\
22470\end{array}$ & $\begin{array}{l}0.2078 \\
22470\end{array}$ & $\begin{array}{l}0.2279 \\
22470\end{array}$ & $\begin{array}{l}0.2077 \\
22470\end{array}$ & $\begin{array}{l}0.2252 \\
14134\end{array}$ & $\begin{array}{l}0.2103 \\
22470\end{array}$ & $\begin{array}{l}0.2105 \\
22470\end{array}$ & $\begin{array}{l}0.2112 \\
22470\end{array}$ & $\begin{array}{l}0.2115 \\
22470\end{array}$ & $\begin{array}{l}0.1999 \\
22470\end{array}$ \\
\hline
\end{tabular}

${ }^{*} \mathrm{p}<0.05, * * \mathrm{p}<0.01, * * * \mathrm{p}<0.001$. Robust standard errors, clustered by respondent, in parentheses. All regressions include India and China dummies and fixed effects for survey year, year of PhD, and 2-digit field of study and additional controls listed in Table 2 note. Column (7) also includes India X excess demand and China X excess demand. Col (8) also includes India X rank51-200, India X rank201+ and similarly for India. Col (9) also includes India X country-field rank, China X country-field rank. 